JOSY ALVARENGA CAL

\title{
HISTOLOGIA DO TRATO DIGESTÓRIO DE SURUBIM-PINTADO (PSEUDOPLATYSTOMA CORUSCANS - AGASSIZ - 1829)
}

São Paulo

2006 
JOSY ALVARENGA CAL

Histologia do trato digestório de surubim-pintado (Pseudoplatystoma coruscans - Agassiz - 1829)

Dissertação apresentada ao Programa de Pós-Graduação em Anatomia dos Animais Domésticos e Silvestres da Faculdade de Medicina Veterinária e Zootecnia da Universidade de São Paulo para a obtenção do título de Mestre em Ciências

Departamento:

Cirurgia

Área de concentração:

Anatomia dos Animais Domésticos e Silvestres

Orientador:

Prof. Dr. Francisco Javier Hernandez Blazquez

São Paulo

2006 
Autorizo a reprodução parcial ou total desta obra, para fins acadêmicos, desde que citada a fonte.

\section{DADOS INTERNACIONAIS DE CATALOGAÇÃO-NA-PUBLICAÇÃO}

(Biblioteca Virginie Buff D’Ápice da Faculdade de Medicina Veterinária e Zootecnia da Universidade de São Paulo)

T.1810

Cal, Josy Alvarenga

Histologia do trato digestório do surubim-pintado (Pseudoplatystoma coruscans - Agassiz, 1829) / Josy Alvarenga Cal. - São Paulo: J. A. Cal, 2006.

$87 \mathrm{f}$. : il.

Dissertação (mestrado) - Universidade de São Paulo. Faculdade de Medicina Veterinária e Zootecnia. Departamento de Cirurgia, 2006.

Programa de Pós-graduação: Anatomia dos Animais Domésticos e Silvestres.

Área de concentração: Anatomia dos Animais Domésticos e Silvestres.

Orientador: Prof. Dr. Francisco Javier Hernandez Blazquez.

1. Histologia. 2. Trato digestório. 3. Anatomia e histologia. 4. Pseudoplatystoma coruscans. I. Título. 


\section{UNIVERSIDADE DE SÃO PAULO \\ Faculdade de Medicina Veterinária e Zootecnia}

Cidade Universitária "Armando de Salles Oliveira"

\section{Comissão de Bioćtica}

\section{CERTIFICADO}

Certificamos que o Projeto intitulado "Histologia do trato digestório de Surubim Pintado (Pseudoplatystoma caruscans Agassiz 1829)", protocolo n618/2005, utilizando 12 surubins, sob a responsabilidade do Prof. Dr. Francisco Javier Hernandez Blazquez, está de acordo com os principios éticos de experimentação animal da Comissão de Bioética da Faculdade de Medicina Veterinária e Zootecnia da Universidade de São Paulo e foi aprovado "ad referendun".

(We certify that the Research "Histology of the digestive tract of Surubim Pintado (Pseudoplatystoma coruscans Agassiz 1829)", protocol number $618 / 2005$, utilizing 12 surubins, under the responsibility of Prof. Dr. Francisco Javier Hernandez Blazquez, agree with Ethical Principles in Animal Research adopted by Bioethic Commission of the Faculty of Veterinary Medicine and Zootechny of University of São Paulo and was approved "ad referendun", meeting).

São Paulo, 28 de março de 2005

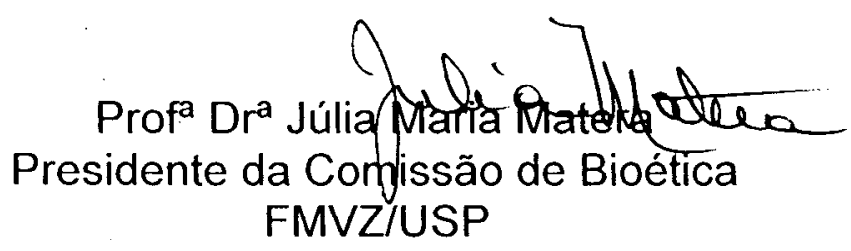




\section{FOLHA DE AVALIAÇÃO}

Nome: CAL, Josy Alvarenga

Título: Histologia do trato digestório de surubim-pintado (Pseudoplatystoma coruscans - Agassiz, 1829)

Dissertação apresentada ao Programa de Pós-Graduação em Anatomia dos Animais Domésticos e Silvestres da Faculdade de Medicina Veterinária e Zootecnia da Universidade de São Paulo para a obtenção do título de Mestre em Ciências

Data: I-_- 1

Banca Examinadora:

Prof. Dr. Instituição:

Assinatura: Julgamento:

Prof. Dr. Instituição:

Assinatura: Julgamento:

Prof. Dr. Instituição:

Assinatura: Julgamento: 


\section{DEDICATÓRIAS}

\section{A Deus}

Por ser a minha força, meu refúgio, sempre presente nas horas difíceis e também sempre a razão de minha alegria. Ele é aquele que me guia, que governa a minha vida e me enche de paz e coragem em todos os momentos. Dedico a um Deus Vivo e zeloso, não só este trabalho, mas toda a minha vida!

"Não temas, porque eu sou contigo, não te assombres, porque eu sou teu Deus, eu te fortaleço, e te ajudo e te sustento, com a minha destra fiel." 


\section{DEDICATÓRIAS}

À minha mãe (Sonia Mara)

Por ter sempre acreditado em mim, me ajudando a levantar nos momentos difíceis e me reanimado sempre com suas amorosas palavras e sua força. Eu te agradeço por toda a dedicação, por cada cuidado e cada gesto que fez por mim nessa trajetória. Te agradeço por ser essa pessoa maravilhosa, certamente é um exemplo de vida e determinação para mim. Obrigada pelo amor, companheirismo e pelas preciosas orações. Dedico a você, mãe, este trabalho, com todo amor $e$ carinho e com muito orgulho de poder abraçá-la neste dia e dizer: Muito obrigada por tanto amor querida! 


\section{DEDICATÓRIAS}

À minha irmã (Christy)

Por sempre ter torcido por mim, me ajudado com palavras de ânimo em tantos momentos que precisei. Eu te agradeço minha irmã querida pois você, mesmo longe, esteve presente, por meio de orações e de palavras tão carinhosas e reconfortantes. Obrigada por existir e por ter tanto carinho, por todos os sacrifícios passados e pela sua compreensão. Eu te admiro muito e reconheço seu valor. Muito obrigada por toda a força!

Ao meu pai (José Cal Vidal)

Por ter me incentivado a alçar vôo e acreditado que eu conseguiria realizar meus sonhos, pois sempre percebeu meu amor pelo que faço. Agradeço-lhe por tantos conselhos, sempre buscando promover meu crescimento profissional e humano. Eu o admiro muito e dedico a você este trabalho, como forma de agradecimento por toda a torcida e incentivo. 


\section{"Sou livre?}

Sou livre quando amo o que faço.

Sou livre quando aceito que o mais importante é a minha consciência.

Sou livre quando sei que na hora do fracasso, é sempre tempo de começar outra vez.

Sou livre quando sou capaz de amar o instante da vida que eu tenho nas mãos." 


\section{AGRADECIMENTOS}

> Ao Prof. Dr. Francisco Javier Hernandez Blazquez, por sua orientação, pelo seu incentivo e apoio e por ter sempre acreditado em mim. Muito obrigada por me transmitir seus preciosos conhecimentos tão essenciais para meu crescimento profissional.

> À Profa. Dra. Maria Angélica Miglino por ter me recebido no Programa de pósgraduação em Anatomia dos Animais Domésticos da FMVZ e com isso ter tornado possível a realização de uma importante etapa em minha vida.

> A todos os Professores do Curso de Pós-Graduação em Anatomia dos Animais Domésticos da FMVZ pelos conhecimentos transmitidos e pela disposição em ajudar.

$>$ Ao Prof. Dr. Gilberto Valente Machado, meu grande mestre, que sempre me incentivou, aconselhou e se alegrou com todas as minhas vitórias. Por ter sempre me estendido a mão para ajudar e acreditado no meu potencial. Agradeço, sobretudo, por ter sido aquele que através de sua competência $e$ brilhantismo me abriu os olhos para o mundo fascinante da Anatomia.

> Ao Prof. Dr. José Roberto Machado Cunha da Silva, pela preciosa e importante ajuda em disponibilizar a estrutura física para acomodação dos animais no Biotério de Animais Aquáticos do Laboratório de Histofisiologia Evolutiva do ICB - USP e também pelas contribuições científicas que foram importantes para o desenvolvimento do presente trabalho.

$>$ A Leandro Nogueira Pressinotti e João Carlos Shimada Borges, do ICB - USP, que colaboraram gentilmente neste trabalho, transmitindo conhecimentos $e$ sempre dispostos a ajudar.

Ao sr. Marcelo Leite, proprietário do Pesqueiro "Pintado na Brasa" e demais pessoas deste estabelecimento que contribuíram na importante fase do trabalho referente à captura e acondicionamento dos peixes. 
Em memória aos animais, agradeço respeitosamente, pois tive a oportunidade de obter valiosos conhecimentos científicos ao longo desse período em que os estudei.

- A CAPES, pela bolsa de Demanda Social concedida.

- Aos funcionários da Secretaria do Setor de Anatomia, Maicon Barbosa da Silva e Jaqueline Martins de Santana, pela amizade e pelo auxílio precioso em diversos momentos necessários.

- As funcionárias da Secretaria da Pós-Graduação da FMVZ, Claudia Lima, Dayse Maria Alves Flexa e Joana Vasconcellos, pelo gentil suporte, pela atenção e valiosa ajuda que sempre me dispensaram.

> Aos funcionários e técnicos no Setor de Anatomia, Diogo Nader Palermo, Edinaldo Farias (Índio), Ronaldo Agostinho da Silva, Sandra Affonso, Paolo, Cauê Lima, Raimundo Leal de Sousa, João do Carmo Freitas e Branca, por sempre estarem dispostos a ajudar e pela amizade que cultivam em nosso ambiente de trabalho.

$>$ Aos demais funcionárias por zelarem pela limpeza e demais afazeres junto ao Setor de Anatomia.

> As funcionárias da Biblioteca da FMVZ, pela disposição em ajudar e por todo auxílio prestado quanto a busca de informações bibliográficas.

A todos os funcionários da Faculdade de Medicina Veterinária e Zootecnia da Universidade de São Paulo, por auxiliarem com presteza nos diversos assuntos essenciais para o andamento do trabalho científico.

> Aos funcionários do Setor de Informática da FMVZ-USP, Antônio, Miro, Rubens, Camila e Luis, pela amizade, pelo importante apoio computacional e pela disposição em ajudar em tantos momentos cruciais para realização deste trabalho. 
D A técnica Marta da Silva Righetti, do ICB - III (USP), pela dedicada colaboração técnica e pelo empréstimo de material didático e científico para consulta.

> Ao Nilton Pedro dos Santos, técnico do Laboratório de Biologia Celular e de Histologia da FZEA - Pirassununga, pelo auxílio e suporte técnico quanto ao material de historresina.

> A todos os colegas do curso de Pós-Graduação, agradeço por todo apoio e por tantos momentos compartilhados.

Aos amigos e companheiros no Laboratório de Imumo-histoquímica e Anatomia Microscópica, Diogo Palermo, Ana Paula Silva, Tânia, Thiago Aloia, Alex Santos, Gisele Saviane, Ricardo Guerra, Cíntia, Bruno Cogliati, Fernanda Agreste, pela amizade e por todo auxílio que cada um já me prestou, contribuindo para o desenvolvimento do experimento e por vários momentos agradáveis que passamos juntos.

$>$ Em especial agradeço a minha grande amiga Elizângela dos Anjos Silva, que em tantos momentos esteve do meu lado, me incentivando e ajudando em muitas horas difíceis. Muito obrigada amiga, por tudo que fez por mim e acima de tudo, pela amizade verdadeira! Agradeço a Deus pela sua vida!

Ao amigo Hildebrando Gomes Benedicto, por toda preciosa ajuda e pela amizade. Agradeço muito pela força, pelos conselhos e apoio dispensados a mim. Muito obrigada, amigo, pelas orações e todo suporte que recebi.

> As minhas amigas e companheiras de moradia, Procássia Maria Lacerda e Karla Patrícia Araújo, pela companhia, solidariedade e amizade. Agradeço por tudo de bom que fazem por mim e por todos os momentos bons e alegres que passamos juntas.

Aos amigos de Lavras, que jamais deixaram de me apoiar e acreditar em mim, em especial Érika Heindenreich da Rocha, Lívia Maria Chamma Davide, Janine França, Belami Silva, Giovana Alcântara Maciel, Lílian Naomi Numajiri, Natália, Everton Borges, Flavio Faria, Julio César Carrera, Leandro Batista, Cleube Boari que de uma maneira muito especial sempre se fizeram presentes e por torcerem sempre por mim. Amigos verdadeiros, muito obrigada! 
Aos amigos e incentivadores, Prof. Dr. Henrique Ribeiro Alves Resende, Prof. Dr. João Chrysostomo de Resende Júnior, Prof. Dr. Luciano da Silva Alonso, pela amizade e motivação recebida durante a minha formação acadêmica em Lavras.

> Aos irmãos em Cristo: Cláudio e Carmem, Ana Carolina, Rildo e Alessandra pelo contínuo suporte em orações, intercedendo sempre pela minha vida e meu trabalho, agradeço. Peço a Deus que os retribua em bênçãos!

$>$ A todos os membros da Igreja Evangélica em Cidade Universitária (IECUSP), em especial ao Pastor James Missé, Silvia Missé, Clarice Killing (tia Clá), Priscila Killing, Jefferson e Claudinha, Cristiane e Alexandre, Flávio e todos os demais, pois enfim, vocês constituem a família que Deus me deu aqui em São Paulo.

> Aos grandes amigos Ricardo e Cláudia Brito por tudo que sempre fizeram por mim, por terem me acolhido e sempre se preocupado comigo desde que aqui cheguei, e também ao Pastor Eliel Batista e Gislene pela amizade preciosa de longa data e Pastor Sergio e Selma, que no início também me acolheram em sua casa e pela força e orações.

A todos da minha família, que, mesmo estando longe, sempre me dispensaram carinho e apoio, me desejando sempre o melhor. $E$ à vó Lia, pelo amor e torcida durante todo esse período.

> Aos queridos tios Cristina Maia e José Romero, agradeço a Deus por ter colocado em nossas vidas pessoas tão especiais e amorosas como vocês. Nunca vou me esquecer da preciosa ajuda que fizeram por mim, tão carinhosamente $e$ apesar das dificuldades. Não tenho palavras para agradecer... Essa vitória também é de vocês, pois estiveram do meu lado, torcendo e se preocupando comigo!

> A todos que, de alguma maneira torceram por mim e me apoiaram, contribuindo direta ou indiretamente para a realização deste trabalho, muito obrigada! 


\section{RESUMO}

CAL, J. A. Histologia do trato digestório de Surubim-Pintado (Pseudoplatystoma coruscans - Agassiz, 1829). [Histology of the digestive tract of Surubim-Pintado (Pseudoplatystoma coruscans - Agassiz, 1829)]. 2006. $87 \mathrm{f}$. Dissertação (Mestrado em Ciências) - Faculdade de Medicina Veterinária e Zootecnia, Universidade de São Paulo, São Paulo, 2006.

O pintado (Pseudoplatystoma coruscans), também comumente chamado de surubim é um dos peixes mais apreciados pelo mercado consumidor brasileiro, devido à excelente qualidade do filé. No entanto, trabalhos sobre a morfologia do seu trato digestório são escassos. No presente trabalho, a descrição histológica do esôfago, estômago e intestino do pintado, visa contribuir e fornecer subsídios científicos para compreensão dos processos digestivos dessa espécie. Foram obtidas amostras do esôfago, estômago e de todas as regiões intestinais e posteriormente analisadas à microscopia óptica. No esôfago, observou-se epitélio de revestimento do tipo pavimentoso estratificado não-queratinizado, apresentando células epiteliais, mucosas e grande quantidade de células claviformes. A presença de células claviformes são indicadores de que este órgão está sujeito a lesão e lacerações, participando no sistema de defesa do organismo. O estômago do pintado constituise de um órgão em forma de J, distinguindo-se três regiões: cárdica, fúndica e pilórica. O epitélio de revestimento encontrado é do tipo colunar simples. A superfície epitelial é interrompida pelas criptas gástricas, no fundo das quais se abrem as glândulas gástricas, sendo estas criptas mais profundas na região cárdica ou proximal do estômago. As glândulas gástricas apresentam-se maiores e mais numerosas no segmento proximal, diminuindo em quantidade e tamanho no sentido caudal, o que está relacionado a uma maior demanda na secreção de muco para proteção e digestão de proteínas. O intestino do pintado constitui-se de três regiões distintas e denominadas: intestino proximal, intestino médio e intestino distal ou reto. No epitélio intestinal foram encontrados macrófagos e linfócitos indicando uma barreira celular de defesa no organismo. No intestino distal, observou-se epitélio com cutícula estriada mais baixa do que nos segmentos anteriores. Podemos concluir 
que o pintado apresenta características particulares quanto à estrutura microscópıca do seu trato digestório, em alguns aspectos, se comparado a outros teleósteos.

Palavras-chave: Histologia animal. Trato digestório. Anatomia e histologia. Pseudoplatystoma coruscans. 


\section{ABSTRACT}

CAL, J. A. Histology of the digestive tract of Surubim-Pintado (Pseudoplatystoma coruscans - Agassiz, 1829). [Histologia do trato digestório de Surubim-Pintado (Pseudoplatystoma coruscans - Agassiz, 1829)]. 2006. $87 \mathrm{f}$. Dissertação (Mestrado em Ciências) - Faculdade de Medicina Veterinária e Zootecnia, Universidade de São Paulo, São Paulo, 2006.

Pintado (Pseudoplatystoma coruscans), also commonly called surubim, is one of the most appreciated fish by the Brazilian consumer market, due to the excellent filet quality. However, works on the morphology of their digestive tract are scarce. In this work, the histological description of the esophagus, stomach and intestine of pintado, seeks to contribute and to supply scientific information for the better understanding of the digestive process of these species. Samples were obtained from esophagus, stomach and from all the intestinal areas and later analyzed with light microscope. In the esophagus, epithelium is stratified pavimentous type and was observed no queratinization, presenting epithelial cells, mucous membranes and great amount of club cells. The presence of club cells indicates that this organ is subjected to lesion and lacerations, participating in the organism defense system. The stomach of pintado is constituted of an organ in $\mathrm{J}$ form, being there distinguished three areas: cardic, fundic and piloric. The epithelium of the stomach is simple colunar type. The epithelial surface is interrupted by the gastric crypts, in the bottom of which opens up the gastric glands, being these deeper crypts in the cardic area or proximal of the stomach. The gastric glands come larger and more numerous in the proximal segment, decreasing in amount and size in the caudal way, what is related to a larger demand in the mucus secretion for protection and digestion of proteins. The pintado's intestine is constituted of three different areas and denominated: proximal intestine, medium intestine and distal intestine or rectum. In the intestinal epithelium there were found macrophages and lymphocytes indicating a cellular barrier for the organism defense. In the distal intestine, epithelium was observed with cuticle grooved lower than in the previous segments. We can conclude that pintado presents private 
characteristics in relation to the microscopic structure of its digestive tract, in some aspects, if compared to other teleosts.

Key words: Animal histology. Digestive tract. Anatomy and histology. Pseudoplatystoma coruscans. 


\section{LISTA DE ABREVIATURAS}

PAS - Ácido periódico-reativo de Schiff

AB - Azul de Alcian

HE - Hematoxilina e eosina

HF - Hematoxilina e floxina 


\section{LISTA DE ILUSTRAÇÕES}

Figura 1 - Peixes (pintados) no tanque do Biotério de Animais Aquáticos do Laboratório de Histofisiologia Evolutiva do Instituto de Ciências Biomédicas - USP 40

Figura 2- Arranjo do trato digestório na cavidade celomática do pintado, mostrando a localização dos órgãos componentes e sua sintopia. Visão ventral.. 52

Figura 3 - Desenho esquemático das regiões intestinais, baseado em um espécime de P. coruscans.

Intestino Proximal: segmentos 1 - $3 \rightarrow$ Alça 1

Intestino Médio: segmentos 1 - $3 \rightarrow$ Alça 2; segmentos 4 e $5 \rightarrow$ Alça 3 ; segmentos 6 - $8 \rightarrow$ Alça 4

Intestino Distal ou Reto: segmentos 1 - $4 \rightarrow$ Alça 5 .

Quadro 1 - Subdivisão do intestino do pintado em regiões intestinais, suas alças e limites anatômicos - São Paulo - 2006... 


\section{LISTA DE TABELAS}

Tabela 1 - Freqüência de células caliciformes nos segmentos das regiões intestinais do pintado segundo o tipo de mucosubstâncias coradas pelos métodos de coloração histoquímicos - São Paulo - 2006..........61 


\section{LISTA DE APÊNDICES}

Apêndice A - Figura 4 - $\quad$ Fotomicrografias do esôfago do pintado, A e B,mostrando epitélio do tipo pavimentoso estratificado não-queratinizado, com grande presença de células claviformes (seta), em diferentes fases de diferenciação celular e células mucosas presentes na superfície do epitélio (cabeça de seta). HE. Barra $=50 \mu \mathrm{m}$

Figura 5 - Fotomicrografias do esôfago do pintado. A - Observa-se grande quantidade de células mucosas contendo mucopolissacarídeos neutros (seta). PAS. Barra $=200 \mu \mathrm{m}$. B - llustrando a presença das células claviformes (cabeça de seta). HE. Barra $=200 \mu \mathrm{m}$.

Apêndice B - Figura 6 - $\quad$ Fotomicrografias do estômago de pintado ilustrando as suas diferentes regiões e a distribuição de glândulas gástricas (seta) no epitélio. A - Segmento proximal do estômago, com a presença de maiores e mais numerosas glândulas gástricas. HE. Barra $=200 \mu \mathrm{m}$. B - Segmento médio do estômago com menor quantidade de glândulas gástricas e mostrando a cripta gástrica (cabeça de seta). HE. Barra = $200 \mu \mathrm{m}$. C - Segmento distal do estômago mostrando menor quantidade e tamanho de glândulas gástricas. HE. Barra = $200 \mu \mathrm{m}$

Figura 7 - Fotomicrografias do intestino proximal do pintado. A Terceiro segmento onde se visualiza os vilos intestinais e estratigrafia desta região intestinal. HE. Barra $=200 \mu \mathrm{m}$. B Epitélio do terceiro segmento do intestino proximal, evidenciando-se pouca freqüência de células mucosas coradas (cabeça de seta). PAS + AB. Barra $=100 \mu \mathrm{m}$

Apêndice C - Figura 8 -

Fotomicrografias do intestino proximal do pintado. A Terceiro segmento onde se observa o epitélio do tipo colunar simples. HF. Barra $=50 \mu \mathrm{m}$. B - Epitélio do primeiro segmento do intestino proximal, onde podem ser observados vários linfócitos intraepiteliais (cabeça de seta). HF. Barra = $30 \mu \mathrm{m}$

Figura 9 - $\quad$ Fotomicrografias do intestino médio do pintado. A - Primeiro segmento onde se observa o epitélio do tipo colunar simples, pouca freqüência de células caliciformes (seta). PAS. Barra $=50 \mu \mathrm{m}$. B - Epitélio do segundo segmento do intestino médio, onde nota-se detalhe de um macrófago intraepitelial (cabeça de seta). HF. Barra $=50 \mu \mathrm{m}$ 
Apêndice D - Figura 10 -

Apêndice E - Figura 12 -
Fotomicrografias do intestino médio do pintado. A - Terceiro segmento do intestino médio, destacando-se maior freqüência de células caliciformes coradas (seta), se comparado ao segmento anterior. PAS + AB. Barra $=100$ $\mu \mathrm{m}$. B - Epitélio do terceiro segmento do intestino médio. HF. Barra $=50 \mu \mathrm{m}$.

Figura 11 - $\quad$ Fotomicrografias do intestino médio de pintado. A - Glândula intestinal (seta) visualizada no sétimo segmento do intestino médio, apresentando células caliciformes coradas pelos métodos histoquímicos. PAS + AB. Barra $=100 \mu \mathrm{m}$. $\mathbf{B}-$ Detalhe de um macrófago intraepitelial (cabeça de seta), visualizado no último segmento do intestino médio. PAS + AB. Barra $=50 \mu \mathrm{m}$

Fotomicrografias do intestino distal ou reto de pintado. A Epitélio do tipo colunar simples encontrado e borda em escova. HF. Barra $=50 \mu \mathrm{m}$. B - Freqüência de células caliciformes no primeiro segmento do intestino distal. PAS + AB. Barra $=50 \mu \mathrm{m}$.

Figura 13 - $\quad$ Fotomicrografias ilustrando a diferença de altura do epitélio nas diferentes regiões intestinais. A - Epitélio do tipo colunar simples, no quarto segmento do intestino proximal. HF. Barra $=50 \mu \mathrm{m}$. B - Sétimo segmento do intestino médio. HF. Barra $=50 \mu \mathrm{m} \mathrm{C}-$ Segundo segmento do intestino distal ou reto. HF. Barra $=50 \mu \mathrm{m}$ 


\section{SUMÁRIO}

\begin{tabular}{|c|c|}
\hline 1 & 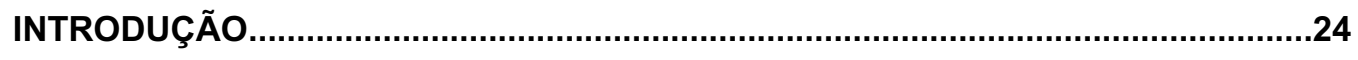 \\
\hline 2 & OBJETIVOS \\
\hline 3 & REVISÃO DE LITERATURA \\
\hline 4 & 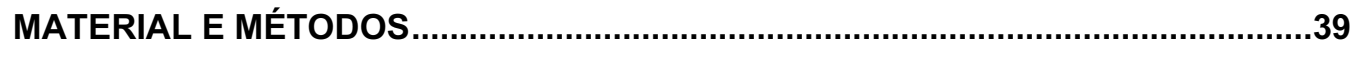 \\
\hline 4.1 & ANIMAIS \\
\hline 4.2 & COLETA, FIXAÇÃO E PROCESSAMENTO PARA MICROSCOPIA ÓPTICA ..............40 \\
\hline 4.3 & MÉTODOS DE COLORAÇÃO E DOCUMENTAÇÃO FOTOGRÁFICA .......................42 \\
\hline 5 & RESULTADOS $\ldots$ \\
\hline 5.1 & ESÔFAGO \\
\hline 5.1 .1 & Mucosa . \\
\hline 5.1.1.1 & Epitélio. \\
\hline 5.1 .1 .2 & Lâmina própria \\
\hline 5.1 .2 & 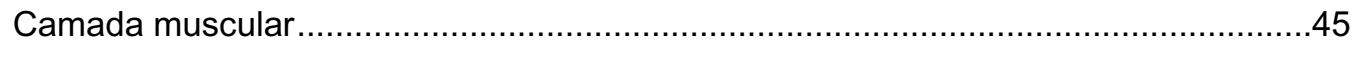 \\
\hline 5.1 .3 & Serosa... \\
\hline 5.2 & ESTÔMAGO ........... \\
\hline 5.2 .1 & Mucosa \\
\hline 2.1 .1 & .46 \\
\hline
\end{tabular}

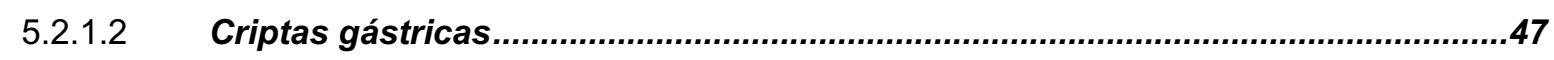

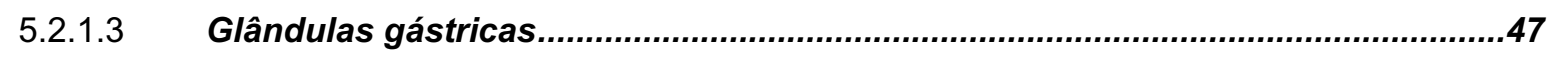

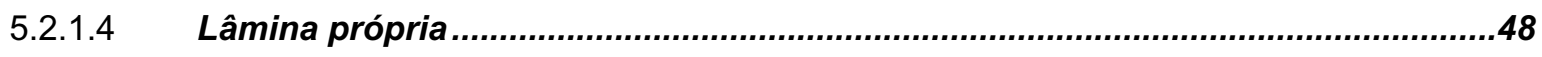

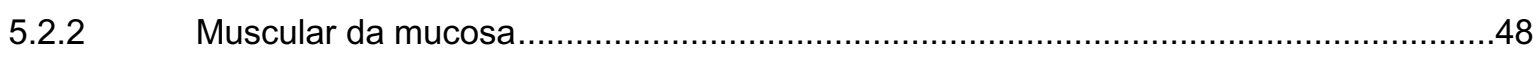

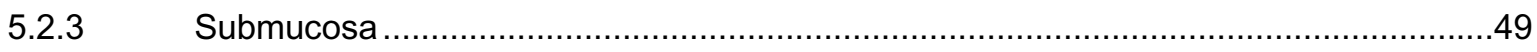

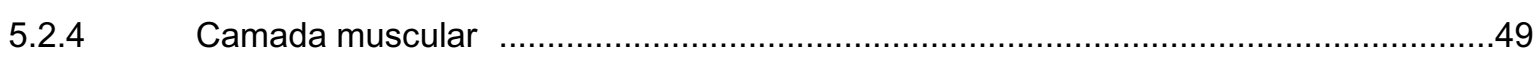

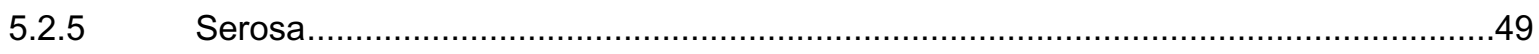

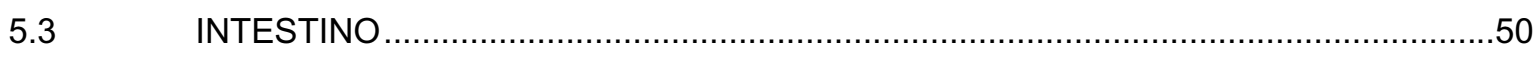

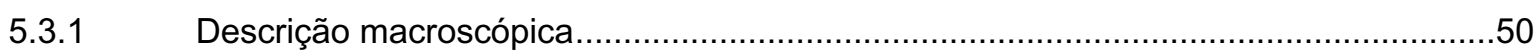




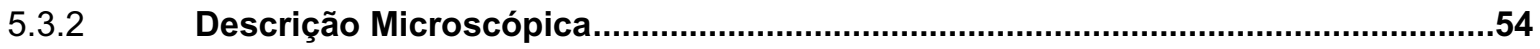

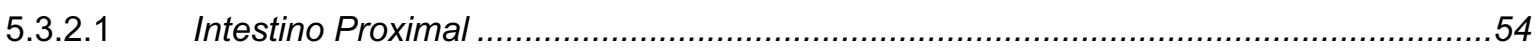

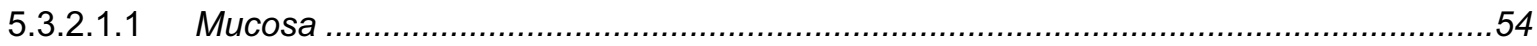

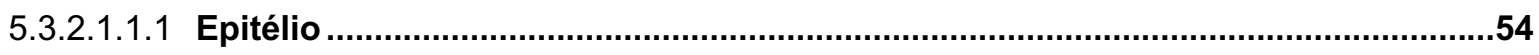

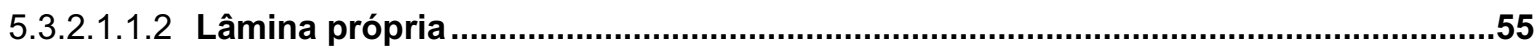

5.3.2.1.2 Submucosa

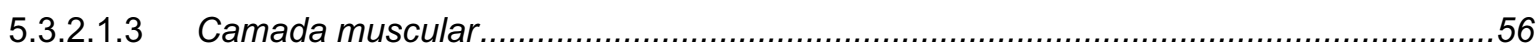

5.3.2.1.4 Serosa

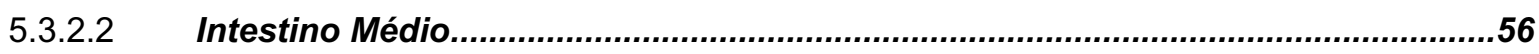

5.3.2.2.1 Mucosa

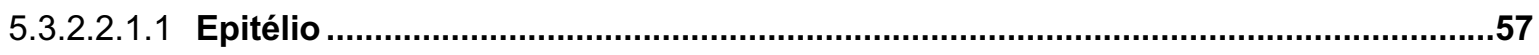

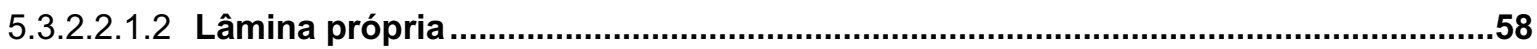

5.3.2.2.2 Submucosa

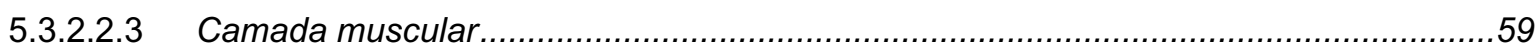

5.3.2.2.4 Serosa

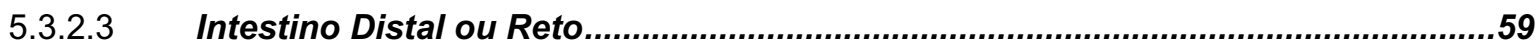

5.3.2.3.1 Mucosa

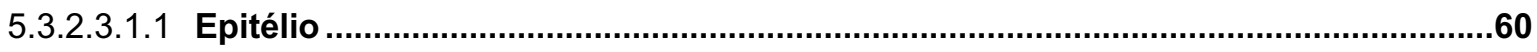

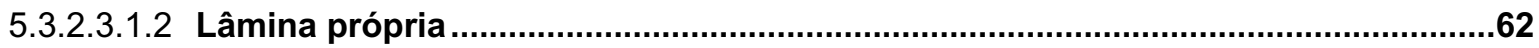

5.3.2.3.2 Submucosa

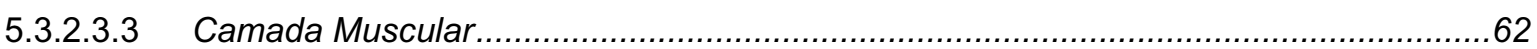

5.3.2.3.4 Serosa

$6 \quad$ DISCUSSÃO

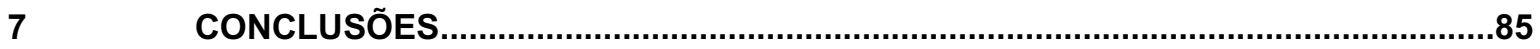

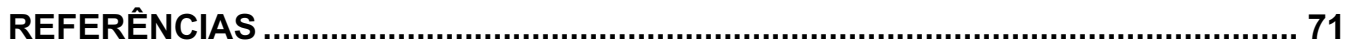

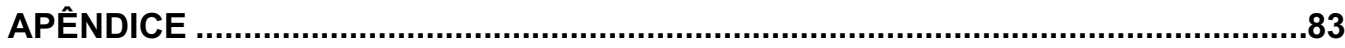




\section{INTRODUÇÃO}

O pintado (Pseudoplatystoma coruscans), também comumente chamado de surubim, é um Siluriforme carnívoro, da família Pimelodidae, proveniente da América do Sul (PETRERE, 1995; WELCOMME, 1985), podendo atingir mais que $120 \mathrm{Kg}$ (SATO et al., 1988). É também conhecido como bagre neotropical e comumente encontrado nas bacias hidrográficas do Prata e do São Francisco (BRITSKI et al., 1999). Trata-se de um dos peixes mais apreciados pelo mercado consumidor brasileiro, devido à excelente qualidade do filé. Esta espécie possui um considerável potencial em aqüicultura, destacando-se como um dos peixes preferidos na pesca de água doce, por possuir um grande porte e também é muito usado como peixe ornamental. Estes fatores somados às ações antrópicas têm contribuído para o decréscimo da população natural. Ainda, segundo Miranda (1997), o pintado possui bons índices zootécnicos, o que contribui para que este seja um animal de excelente potencial comercial.

A piscicultura de água doce no Brasil tem como característica a grande diversidade de espécies. Trata-se de aproximadamente 50 espécies que vêm sendo utilizadas na aqüicultura brasileira. A produção total de peixes em cativeiro somando 132.989 toneladas, era em grande parte proveniente do cultivo de carpas e tilápias (HILSDORF; MOREIRA, 2004).

Estudos histológicos em peixes estão fornecendo inúmeras informações a respeito do trato gastrointestinal. No entanto, existem ainda poucos registros na literatura a respeito da histologia completa do sistema digestório dos peixes dos rios brasileiros e esta necessita de maiores informações que auxiliem na correta localização e delimitação das estruturas do aparelho digestório bem como elucidar questões referentes a adaptações morfológicas frente a variações nutricionais na dieta, tanto a natural como a artificial. 
O conhecimento de características morfofisiológicas do sistema digestório de peixes é essencial para se compreender as suas modificações devido à adaptações a dietas e também para se obter sucesso na criação. Várias correlações entre os hábitos nutricionais e a estrutura do trato digestório de peixes tem sido feitas por numerosos autores (AL-HUSSAINI, 1949; CURRY, 1939; LANGILLE; YOUSON, 1984; MARTIM; BLABER, 1984). Um dos obstáculos encontrados no estudo e compreensão do sistema digestório de teleósteos, diz respeito à intensa diversificação nutricional e morfológica existente, não só entre as diversas espécies, mas até dentro da mesma espécie (BARRINGTON, 1957; STROBAND; DABROWSKI, 1979). A escassez de informações específicas, se comparada com a amplitude de variações encontradas, seria um outro obstáculo para a unificação das informações sobre o sistema digestório de peixes em um corpo coerente de conhecimentos.

Do ponto de vista morfológico, é importante que se conheça a descrição da localização dos órgãos digestórios na cavidade celomática.

Segundo Bertin (1958), o trato digestório dos peixes é dividido em intestino cefálico, que compreende a cavidade bucofaringeana; intestino anterior, que compreende o esôfago e o estômago; o intestino médio que abrange o intestino propriamente dito e o intestino posterior, que inclui o segmento retal. Seixas Filho et al. (2001b) descreveram a disposição do intestino médio e do reto na cavidade peritoneal do pintado, subdividindo o intestino em quatro porções distintas, chamadas pelo autor de alças intestinais. Outros autores também assim procederam com relação a estes segmentos intestinais (MORAES; BARBOLA, 1995; SIS et al., 1979). Contudo, os autores não abordaram a anatomia do estômago do pintado (Pseudoplatystoma coruscans).

O único trabalho que trata da constituição microscópica do sistema digestório do pintado (Pseudoplatystoma coruscans) é o de Seixas Filho et al. (2001a) que verificaram a presença de células endócrinas nos segmentos referentes ao intestino médio e ao reto no $P$. coruscans. E ainda, os mesmos autores observaram células 
argirófilas entre as células absortivas, que são o principal constituinte do epitélio intestinal para essa espécie de teleósteo, contudo os outros aspectos da microscopia do intestino não foram descritos.

Embora existam alguns estudos sobre os aspectos fisiológicos do sistema digestório do pintado (BUDDINGTON et al., 1997; LUNDSTEDT et al., 2004), os trabalhos sobre a morfologia do trato digestório são escassos, em particular sobre o grupo de peixes siluriformes, no qual o pintado figura entre os mais importantes do ponto de vista de interesse comercial.

Apesar dos estudos acima mencionados, que denotam um interesse no sistema digestório do pintado, não existem trabalhos publicados na literatura que façam um estudo detalhado da histologia, histoquímica e histofisiologia do tubo digestório do $P$. coruscans. Assim, realizamos um estudo da estrutura microscópica do trato digestório do pintado, do esôfago ao reto, verificando também a distribuição das células mucosas e o tipo de muco produzido, visando conhecer melhor e dar subsídios científicos para compreensão dos processos digestivos dessa espécie, contribuindo com isso para aumentar os conhecimentos a respeito da morfofisiologia do sistema digestório. 


\section{OBJETIVOS}

1 - detalhar a estrutura microscópica do esôfago do pintado (Pseudoplatystoma coruscans), a histoquímica do muco intraepitelial, e estudar a estratigrafia da parede do órgão;

2 - detalhar a estrutura microscópica do estômago do pintado, bem como a histoquímica de sua produção mucosa e a estratigrafia de sua parede;

3 - realizar o estudo da estrutura microscópica do intestino do pintado, histoquímica do muco secretado e estudo da estratigrafia de sua parede. 


\section{REVISÃO DE LITERATURA}

O Pseudoplatystoma coruscans figura como um dos mais apreciados peixes de água doce da ordem Siluriformes e subordem siluroidei, os quais são peixes de couro, assim chamados por serem desprovidos de escamas (SANTOS, 1987). Seu corpo é revestido apenas de pele espessa, ou coberto, parcial ou totalmente, com placas ósseas (SANTOS, 1981). Apresentam barbilhões, em geral um par maxilar e dois pares mentonianos e, freqüentemente, o primeiro raio da nadadeira dorsal e das peitorais se constitui de um acúleo forte e pungente (BRITSKI; SATO; ROSA, 1988). O P. coruscans é também conhecido pelos nomes vulgares pintado, surubim, surubi, surumbi e surumi, para designar este peixe na Amazônia. Trata-se de um dos maiores peixes fluviais, podendo atingir 3 metros de comprimento corpóreo, rivalizando assim em tamanho com a piraíba. Ocorre na bacia do São Francisco, bem como na do Rio do Prata e Paraguai. Distingue-se do Pseudoplatystoma fasciatum o qual possui estreitas raias transversais obscuras, algumas orladas de branco, sobre o pardo claro do dorso e dos flancos, com o ventre branco e nacarado. Ainda, o $P$. coruscans possui o processo occipital truncado, quase alcançando a placa predorsal, tendo o corpo manchas negras e redondas, e o $P$. fasciatum, o processo occipital lanceolado, com seu extremo bem afastado da placa predorsal (SANTOS, 1987).

Esta espécie, entre os surubins é a mais importante em relação a sua exploração industrial. Na Bahia vem-se realizando sua industrialização, sendo o produto obtido denominado de "bacalhau nacional".

Este peixe gosta de freqüentar o fundo dos rios onde as águas se mostram em remanso. Como a maioria dos Siluriformes, tem vida noturna, caçando pequenos peixes, crustáceos, vermes e, ao engoli-los, ingere também lama e areia grossa. Este peixe desova de dezembro a fevereiro (SANTOS, 1987). 
Segundo Lauder e Liem (1983) o pintado apresenta a seguinte sistemática: super classe - Pisces; classe - Osteichthyes; subclasse - Actinopterygii; ordem Siluriformes; subordem - Siluroidei; família - Pimelodidae; gênero Pseudoplatystoma Bleeker, 1862; espécie - Pseudoplatystoma coruscans (Agassiz, 1829).

Alguns autores como Suyehiro (1942), Al-Hussaini (1949) e Angelescu e Gneri (1949), entre outros, demonstraram que existe uma correlação entre as estruturas do aparelho digestório e os hábitos alimentares de peixes. Wootton (1990) enfatizou que deve haver convergência evolutiva a respeito da morfologia de espécies não relacionadas filogeneticamente e que apresentam recursos alimentares semelhantes.

Apesar das relações entre a morfologia do aparelho digestório e da dieta de peixes estarem sendo bem documentadas (AL-HUSSAINI, 1949; ANGELESCU; GNERI, 1949; JUNGER et al., 1989; VEREGINA, 1990), as variações morfológicas dentro de categorias tróficas em peixes tropicais parecem ser escassamente exploradas, especialmente entre peixes detrívoros e demais espécies bentônicas.

O esôfago dos teleósteos é descrito como um segmento do tubo digestório que tem o papel de unir a faringe ao estômago (AL-HUSSAINI, 1946; GODINHO, 1967; MARTIM; BLABER, 1984; SIS et al., 1979), possuindo a luz pregueada (LIEM, 1967; SIS et al. 1979). Seu epitélio de revestimento é bastante variável de acordo com a espécie, podendo ser pavimentoso estratificado ou colunar estratificado e com células mucosas (CLARKE; WITCOMB, 1980; KAPOOR et al., 1975; MARTIM; BLABER, 1984), sendo encontrados três tipos diferentes de células mucosas: as secretoras de mucopolissacarídeos neutros, ácidos ou ainda as produtoras de ambos (EZEASOR, 1984; REIFEL; TRAVILL, 1978). Encontram-se ainda outros tipos de células presentes neste epitélio (GODINHO et al., 1970), tais como células claviformes e células poliédricas. Em alevinos de pintado, foram encontradas células claviformes em pequena quantidade no esôfago, prevalecendo a ocorrência de células mucosas e a não queratinização do epitélio (SOUZA, 1999). O esôfago de 
algumas espécies de peixes pode também ser revestido por epitélio colunar simples (MOHSIN, 1962; TAN; TEH, 1974), encontrando-se ainda o epitélio cúbico estratificado (WEINREB; BILSTAD, 1955) e o epitélio colunar, prismático ou cilíndrico estratificado (BLAKE, 1936). Há relatos da presença de glândulas esofagianas em peixes (BLAKE, 1930; EZEASOR, 1984; MOHSIN, 1962).

O estômago dos teleósteos possui conformações variadas que Bertin (1958) agrupou em três categorias gerais: o tipo sifonal, o cecal e o retilíneo. $O$ primeiro comporta um ramo descendente chamado de cárdico e um ascendente, o ramo pilórico. No estômago cecal, a estes dois segmentos se interpõe uma região de união, em fundo cego. O estômago retilíneo é o menos freqüente dos três (MARTIM; BLABER, 1984).

Alguns autores divergiram de Bertin (1958) quanto a divisão dos segmentos. Assim, Gomes (1981) e Kuchinski (1985), dividiram o órgão em região cárdica, fúndica e pilórica, tomando como critério a estrutura anatômica e a presença ou não, de glândulas gástricas. E ainda, segundo Suyehiro (1942), o estômago de peixes pode apresentar a forma das letras $U, \mathrm{~J}$ ou $\mathrm{Y}$.

A parede gástrica compreende as quatro camadas típicas encontradas em todos os vertebrados, ou seja, a mucosa, a submucosa, a muscular e a serosa (KAPOOR et al., 1975).

A mucosa forma pregas que podem ser longitudinais (RAY; MOITRA, 1982), percorrer um trajeto tortuoso (VERIGINA, 1974), ou ainda entrecruzar-se, resultando um aspecto reticulado (VERMA; TYAGI, 1974). Além das pregas primárias, existem ainda as pregas secundárias (MARTIM; BLABER, 1984). Em alguns animais, as pregas desaparecem no terço final da região cárdica (VERIGINA, 1979).

O estômago dos peixes é geralmente revestido por epitélio prismático simples (DOMITROVIC; MOREIRA, 1984; KAPOOR et al., 1975). Porém, alguns autores encontraram epitélio pseudo-estratificado, cúbico estratificado, prismático simples ciliado e prismático estratificado (WEISEL, 1973) e ainda pavimentoso simples (PETRINI, 1961) 
revestindo o estômago de algumas espécies de peixes. No epitélio gástrico de peixes há a presença de microvilosidades, segundo Ezeasor e Stokoe (1980).

A submucosa é formada por tecido conjuntivo frouxo, contendo vasos sanguíneos, fibras e gânglios nervosos (BURNSTOCK, 1959), e células adiposas (KESSLER et al., 1979).

A camada muscular da mucosa faz-se presente em algumas espécies e é constituída por fibras musculares lisas de orientação tanto circular como longitudinal (GOMES, 1981; KUCHINSKI, 1985).

A camada muscular é usualmente composta por duas subcamadas de músculo liso, uma circular interna e outra longitudinal externa, porém mudanças desse padrão foram descritas em diferentes peixes, com músculo estriado esquelético formando a subcamada circular interna (ALVES, 1971; KUCHINSKI, 1985). A inversão na disposição tradicional das subcamadas ocorre na região proximal, sendo a subcamada interna longitudinal e composta por músculo estriado (KESSLER et al., 1979).

A serosa é muito delgada e vascularizada contendo vasos sanguíneos, nervos e melanóforos (GEISTDOERFER, 1981).

Alguns autores correlacionam as glândulas gástricas com os hábitos alimentares, sendo que peixes carnívoros vorazes podem possuir glândulas gástricas elaboradas e complexas (KUCHINSKI, 1985; MOHSIN, 1962; VERIGINA, 1974).

As glândulas gástricas abrem-se tanto no fundo (KAPOOR et al., 1975) como diretamente na superfície do estômago (Martim; Blaber, 1984), porém estão ausentes na região pilórica (MARTIM; BLABER, 1984; VERIGINA, 1979).

Um único tipo celular foi identificado nas glândulas gástricas da maioria dos peixes (KAPOOR et al., 1975; SMIT, 1967), denominada de oxintopéptica e secreta ácido clorídrico (HOLSTEIN, 1975) e enzimas digestivas, à semelhança do que ocorre em anfíbios, répteis (FERRI, 1971) e aves (ANDREW; HICKMAN, 1974) e diferentemente 
do que ocorre nos mamíferos. Grande parte dos teleósteos estudados apresentam criptas gástricas, que são invaginações do epitélio (DOMITROVIC; MOREIRA, 1984; KESSLER et al., 1979), onde desembocam as glândulas gástricas. Nas criptas, pode ser encontrada produção de mucopolissacarídeos ácidos e neutros (REIFEL; TRAVILL, 1978). As glândulas gástricas presentes na mucosa estomacal, são simples e tubulares, contendo as células oxintopépticas (WESTERN; JENNINGS, 1970).

O estômago de Plescotomus commersonii não possui glândulas gástricas ou células oxintopépticas (BORGES, 1981).

A secreção ácida é estimulada pela histamina dos mastócitos. Em adição ao controle secretomotor exercido por hormônios liberados de células endócrinas locais (somatostatina, gastrina), nervos autonômicos estão envolvidos no controle da secreção.

Pouco se sabe a respeito do controle autonômico da secreção da pepsina (pelas células oxintopépticas), secreção de bicarbonato (pela mucosa intestinal e pelo pâncreas exócrino), e secreção mucosa no trato digestório de peixes.

As mudanças no pH estomacal são dependentes do processo digestivo, onde o pH diminui quando ácido é secretado em resposta ao alimento entrando no órgão, seguido pelo aumento no pH quando a secreção ácida é interrompida e a digesta eliminada. $\mathrm{O}$ pH ótimo para a pepsina, em peixes foi determinado para diferentes espécies de peixes (DEGUARA et al., 2003).

Além de colaborar na digestão dos alimentos, conforme comprovado pela presença de ácidos e enzimas digestivas, o estômago também pode ser considerado como órgão auxiliar da respiração (BORGES, 1981).

Muitas espécies de peixes teleósteos das famílias Loricariidae e Trichomycteridae utilizam o estômago como um órgão respiratório acessório. Silva et al. (1997) observaram em que o estômago em Loricariidae consistia de dois sacos cegos respiratórios comunicando-se com o esôfago através de um ducto comum, o 
qual passa para o intestino. Em Ancistrus multispinnis a porção media do estômago (corpo) funciona como um órgão respiratório (SATORA, 1998). Os estômagos respiratórios destas espécies possuem paredes finas e transparentes, onde fibras colágenas são raras, correlacionado com a grande capacidade de distensão deste órgão para se encher de ar. A camada muscular destes estômagos respiratórios é também relativamente fina. Esta camada não é organizada em camadas distintas, mas em pacotes de músculo liso circundados por tecido conjuntivo.

A grande diferença entre os estômagos típicos de teleósteos e aqueles adaptados à respiração reside na camada mucosa. Em estômagos típicos ela forma altas pregas, como em Misgurnus mizolepis (PARK; KIM, 2001) e é revestido por epitélio do tipo colunar simples. Por outro lado, nos estômagos respiratórios a mucosa é delimitada por um epitélio plano. O epitélio de estômagos respiratórios, assim como os sacos respiratórios de Loricariidae, são envolvidos por uma rede de capilares, numa relação nunca observada em estômagos típicos de teleósteos.

Investigações histológicas a respeito do estômago do bagre mostraram que sua estrutura é diferente daquela típica do estômago de outros peixes teleósteos. Sua parede é fina e transparente, enquanto sua camada mucosa é ausente de pregas. O epitélio que recobre toda a superfície interna do estômago consiste de diversos tipos de células, sendo, mais proeminente, as células epiteliais respiratórias. Células endócrinas presentes neste órgão estão envolvidas com a regulação da digestão e provavelmente com a troca local de gases. O estômago desta espécie de peixe possui uma rica trama de capilares, possuindo uma morfologia que sugere ser um órgão eficiente para respiração (PODKOWA, 2003). Este bagre nada até a superfície da água e engole ar, o qual é então armazenado no estômago (ARMBRUSTER, 1998).

O estômago pode estar ausente em alguns teleósteos, conforme relatado por alguns autores (AL-HUSSAINI, 1949; SINHA; MOITRA, 1975; VERIGINA, 1978). E também existem peixes que, como adaptação do trato digestório, possuem um estômago 
eminentemente muscular para auxiliar na trituração mecânica dos alimentos, chamado também de moela (HERNANDEZ BLAZQUEZ et al., 1990; KAPOOR et al., 1975).

Fugi et al. (2001), relataram que o estômago das espécies Prochilodus lineatus e Steindachnerina insculpta possui duas regiões bem delimitadas, a cárdica e a pilórica (chamada de moela) e que, em contrapartida, o estômago de Iheringichthys labrosus e Trachydoras paraguayensis é sacciforme com as porções cárdica e pilórica não bem diferenciadas.

Em Loricariichthys platymetopon, I. labrosus e T. paraguayensis foi relatada a ausência de um estômago bem definido e, associado a este fato, a presença de um dente faríngeo assumindo parte da função mecânica do estômago (ANGELESCU; GNERI, 1949). Estes dentes faríngeos, encontrados nestas espécies, são responsáveis pela trituração ou desmembramento do alimento (LAGLER et al., 1977).

Como exemplo de peixes agástricos, pode-se citar a carpa (Cyprinideo), um peixe que não possui estômago. Sua cavidade oral é preparada para a apreensão, controle, seleção e preparação do alimento para a digestão. A cavidade oral é provida de cumes resistentes de uma membrana pregueada chamada de mucosa. A mucosa é revestida por projeções microscópicas chamadas papilas e é ricamente suprida por células mucosas e receptores gustativos.

A preparação mecânica do alimento se inicia com a ação trituradora dos dentes faríngeos. Situados na parte posterior da cavidade oral, na superfície ventral, existem vários pares de dentes faríngeos, logo abaixo de "almofadas" cornificadas. A trituração feita por esses dentes assegura que o mesmo se encontre suficientemente fragmentado para posterior digestão.

Diferente do que ocorre com outros peixes, que possuem um estômago verdadeiro, a carpa possui meramente uma expansão sacular, a qual não secreta ácido ou enzimas e não termina com um músculo esfíncter pilórico. Para que a carpa utilize os nutrientes alimentares, é necessário desmembrar todas as estruturas complexas em seus menores componentes, para que sejam solúveis em água e 
mais facilmente transportados em torno do corpo pelo sistema sangüíneo para onde for necessário.

Em contraste com os mamíferos, larvas de peixes recém-eclodidas não possuem um estômago, mas desenvolvem o mesmo enquanto crescem. Mas a carpa nunca desenvolve um estômago, sugerindo que permanece na forma juvenil "sem estômago".

A completa ausência de um estômago na carpa significa que não há digestão ácida e não há produção de pepsina em conjunto com ácido clorídrico para a digestão de proteínas. Nos peixes, as enzimas tripsina e quimiotripsina secretadas pelo pâncreas são as responsáveis pela digestão de proteínas. O que não está totalmente claro é como outros peixes e vertebrados aquáticos requerem as principais proteases (enzimas digestivas): pepsina, secretada pelo estômago e tripsina, secretada pelo pâncreas, enquanto a carpa digere satisfatoriamente bem proteínas, na total ausência de pepsina. A ação do ácido estomacal da maioria dos vertebrados é importante para a quebra da natureza física do alimento e promover um pH ótimo para a ação da pepsina. Na carpa, a ação trituradora dos dentes faríngeos, retira a necessidade da ação ácida sobre o alimento. Em peixes, a pepsina atua no estômago num pH ótimo de 2. Como não ocorre secreção de ácido clorídrico em peixes sem estômago, a secreção de pepsina torna-se desnecessária.

É interessante notar que em outros peixes e vertebrados, o suco pancreático e a bile são lançados no sistema digestório depois do estômago. O fato de, na carpa, os ductos pancreático e colédoco entrarem no intestino anteriormente à saculação receptora, sugere que este "saco" não pode ser considerado como uma forma de estômago primitivo ou afuncional.

O tempo de esvaziamento, ou de transito intestinal, na carpa, pode ser de 16 horas a $25^{\circ} \mathrm{C}$ a até 60 horas a $12^{\circ} \mathrm{C}$, demonstrando que as taxas de digestão e ação enzimática aumentam a um valor ótimo com a temperatura.

Fugi et al. (2001) sugerem que as espécies por eles estudadas $P$. lineatus e S. insculpta são fortemente adaptadas ao regime alimentar iliófago devido à conformação de seus estômagos. Sua dieta, baseada em itens que são de difícil digestão (lodo e detritos), necessitam de ação mecânica, a qual nestas espécies é 
desempenhada pelo bem desenvolvido estômago pilórico em forma de moela. Este tipo de estômago primariamente fragmenta o alimento (ODUM, 1968). De acordo com Veregina (1990), a ação de moer é auxiliada por pequenas partículas que acompanham o alimento. Por outro lado, Loricariichthys platymetopon possui uma estrutura acessória que vem sido descrita como um estômago (ANGELESCU; GNERI, 1949; PY-DANIEL, 1984). Silva et al. (1997), concluíram que esta estrutura é um órgão acessório adaptado a respiração. Constitui-se numa adaptação para baixas concentrações de oxigênio dissolvido que ocorrem ocasionalmente no alto Rio Paraná (THOMAZ et al., 1997). I. labrosus e T. paraguayensis possuem estômagos do tipo sacciforme, comum entre os peixes.

A anatomia e histologia do trato digestório de Orthrias angorae foi estudada por Suicmez (2005), evidenciando-se quatro camadas: mucosa, submucosa, muscular e serosa. Foi observado um estômago, com formato de J, apresentando em sua porção cárdica um sistema de pregas em rede e pregas longitudinais nas porções fúndica e pilórica. Uma simples camada de células colunares, PAS positivas apenas em sua porção apical, formam seu epitélio. A parede do esôfago e do estômago se apresenta mais fina do que a do intestino devido à camada muscular desses ser mais delgada. Encontraram-se numerosas glândulas gástricas na camada submucosa do estômago cárdico, mas ausência destas na região pilórica do órgão. Não foram encontrados cecos pilóricos entre o estômago e o intestino.

Jobling (1986) sugere que o volume e a área superficial do alimento podem determinar a taxa de esvaziamento gástrico, assim como a quantidade de energia contida no alimento, agindo diretamente sobre os receptores nervosos localizados no duodeno. E também afirma que a composição do alimento influencia, atuando diretamente na secreção de ácidos e enzimas digestivas e hormônios.

Flowerdew e Grove (1979) verificaram experimentalmente que o tempo de esvaziamento gástrico é significativamente menor quando o alimento é diluído e sugerem que pode variar, também, com a composição do alimento. As interrelações entre os mecanismos fisiológicos e os fatores ambientais exercem, também, considerável influencia sobre a velocidade com que o alimento deixa o estômago. Entre os fatores ambientais, a temperatura parece ser o mais importante, tendo sido 
já analisada por diversos autores. Para Kappor, Smit e Verighina (1975) a temperatura atua sobre a taxa de alimentação, atividade das enzimas digestivas, motilidade gástrica e intestinal, taxa de secreção de sucos digestivos e taxa de absorção intestinal.

O intestino de peixes, sob o ponto de vista histofisiológico, é dividido em três segmentos. O primeiro segmento ou segmento proximal, encontra-se relacionado com a absorção de gorduras (HERNANDEZ-BLAZQUEZ et al., 1989; IWAI, 1969; NOAILLAC-DEPEYRE; GAS, 1974; SIRE et al., 1981) sendo o seu epitélio constituído por células prismáticas altas, também chamadas de células absortivas ou enterócitos e por células mucosas ou caliciformes (AL-HUSSAINI, 1949). Há maior número de células mucosas no intestino proximal devido ao fato de estas possuírem uma função de proteção da superfície dos enterócitos contra o conteúdo proveniente do estômago (LUNDSTEDT et al., 2004). O segundo segmento ou segmento médio é descrito como responsável pela absorção de macromoléculas protéicas (GEORGOPOULOU et al., 1985; ROMBOUT et al., 1985; STROBAND; VAN DER VEEN, 1981), contendo maior número de células caliciformes, em relação ao segmento anterior e elevada concentração de vesículas pinocíticas em sua região supranuclear (STROBAND; VAN DER VEEN, 1981). Neste segmento ainda foi descrito a presença de proteínas marcadoras de pinocitose no citoplasma dos enterócitos, como a ferritina (GEORGOPOULOU et al., 1985; ROMBOUT et al., 1985). Stroband e Van Der Veen (1981) sugeriram ainda que, além da função de auxiliar no processo de absorção de macromoléculas protéicas, este segmento médio possui também importância imunológica, devido a ocorrência de uma barreira imune local, com a presença de macrófagos e células linfóides tanto entre as células absortivas do epitélio intestinal como na lâmina própria (ROMBOUT et al., 1985). A mucosa intestinal do segmento médio apresenta uma população celular de macrófagos bastante superior às demais regiões intestinais (MANNING, 1994). Segundo Georgopoulou e Vernier (1986) e Rombout e Van Den Berg (1989), estudando Cyprinus carpio, a presença de determinantes antigênicos_para a ferritina na superfície externa dos macrófagos intraepiteliais sugere que essas células tenham uma função apresentadora de antígenos. De acordo com estudos já realizados em Prochilodus scrofa por Nachi $(1988,1993)$ e na truta arco-íris por 
Georgopoulou et al. (1985) foi observada capacidade de absorção protéica e sua digestão intracelular, neste segmento, com o uso de ferritina. Kaiserlian (1995) observou ainda que os macrófagos presentes no epitélio_absorvem a ferritina quando esta é transferida para o espaço intercelular. O terceiro segmento ou distal está relacionado com a absorção de água e eletrólitos, com o epitélio diferindo das outras regiões apresentando maior número de células caliciformes e cutícula estriada mais baixa, conforme estudado em alguns teleósteos (NOAILLACDEPEYRE; GAS, 1973; NOAILLAC-DEPEYRE; GAS, 1976; NOAILLAC-DEPEYRE; GAS, 1979; NOAILLAC-DEPEYRE; GAS, 1983).

Há uma grande variação do comprimento do intestino na maioria dos teleósteos estudados, porém, o comprimento relativo de cada segmento intestinal, em porcentagem, se mantém constante, sendo: 60 a $75 \%$ para o segmento proximal, 20 a $25 \%$ para o segmento médio e 5 a $10 \%$ para o segmento distal (NOAILLACDEPEYRE; GAS, 1976; STROBAND et al., 1979). Segundo Hidalgo e Alliot (1987), o comprimento do tubo digestório repercute de maneira importante nos aspectos quantitativos da digestão e absorção de alimento.

Angelescu e Gneri (1949) procuraram relacionar a estrutura da mucosa intestinal com os processos fisiológicos da digestão e absorção, afirmando ser a região com as dobras mais desenvolvidas a mais envolvida com os processos absortivos, o qual também foi observado por Moraes e Barbola (1995).

Seixas Filho et al. (2001b) observaram arranjos intestinais retilíneos em $P$. coruscans, compatível com a morfologia dos demais peixes carnívoros. Ainda, a interrelação entre o arranjo da mucosa e a velocidade de transporte de alimentos sugere que o arranjo retarde o avanço do bolo fecal, resultando em melhor absorção de nutrientes. Segundo Flores Quintana et al. (1997), foi observado bem desenvolvidas a mucosa, submucosa, camadas musculares, membrana serosa e a presença de uma válvula retal em pintado. 


\section{MATERIAL E MÉTODOS}

Os materiais e métodos utilizados estão descritos abaixo.

\subsection{ANIMAIS}

Foram utilizados doze exemplares adultos de pintado (Pseudoplatystoma coruscans), mantidos em condições intensivas de criação, provenientes do Pesqueiro "Pintado na Brasa" situado em Guararema, São Paulo. No pesqueiro, os animais são mantidos em mini-represas, de 4 metros de profundidade, com fornecimento de água contínua proveniente de nascente. A alimentação destes peixes constitui-se de ração para peixes carnívoros (Socil) contendo $40 \%$ de proteína bruta, $10 \%$ de extrato etéreo, vitamina C $500 \mathrm{mg}$, mais insumos, além do fornecimento de peixes vivos tais como cará, lambari, tilápia e traíra. Os peixes foram coletados no referido pesqueiro utilizando-se anzol e foram mantidos cativos em tanques-rede às margens do lago. Subseqüentemente foram transportados em grandes caixas plásticas com capacidade para 150 litros de água aproximadamente, contendo água da própria lagoa, e foram colocadas duas bombas de água (Better 500), para garantir a oxigenação durante o transporte, até o Instituto de Ciências Biomédicas da Universidade de São Paulo (ICB - USP). Os animais permaneceram em tanque com capacidade de 1500 litros, no Biotério de Animais Aquáticos do Laboratório de Histofisiologia Evolutiva do Instituto de Ciências Biomédicas - USP (Figura 1). A água utilizada neste tanque provinha de um reservatório elevado, com capacidade para 2000 litros, equipado com filtro Cuno de 10 micrômetros e a água era proveniente da rede e declorada com tiossulfato de sódio. $\mathrm{O} p H$ da água se manteve em torno de 6,5. A temperatura média da água foi mantida entre 22,0 e $24,0{ }^{\circ} \mathrm{C}$, com o uso de aquecedores com termostato (Heater Seven Star AC 110$120 \mathrm{~V} 8$ " 100W), e aferida constantemente utilizando-se termômetro de mercúrio de 
máxima e mínima. Foram utilizados animais com dados homogêneos na relação peso/comprimento, tendo sido registrados o peso médio de $2,9 \mathrm{Kg} / a n i m a l$ e o comprimento corporal total médio de $0,72 \mathrm{~cm}$.

Os peixes permaneceram em jejum, desde a captura, para garantir 0 esvaziamento gástrico e intestinal para coleta dos segmentos.
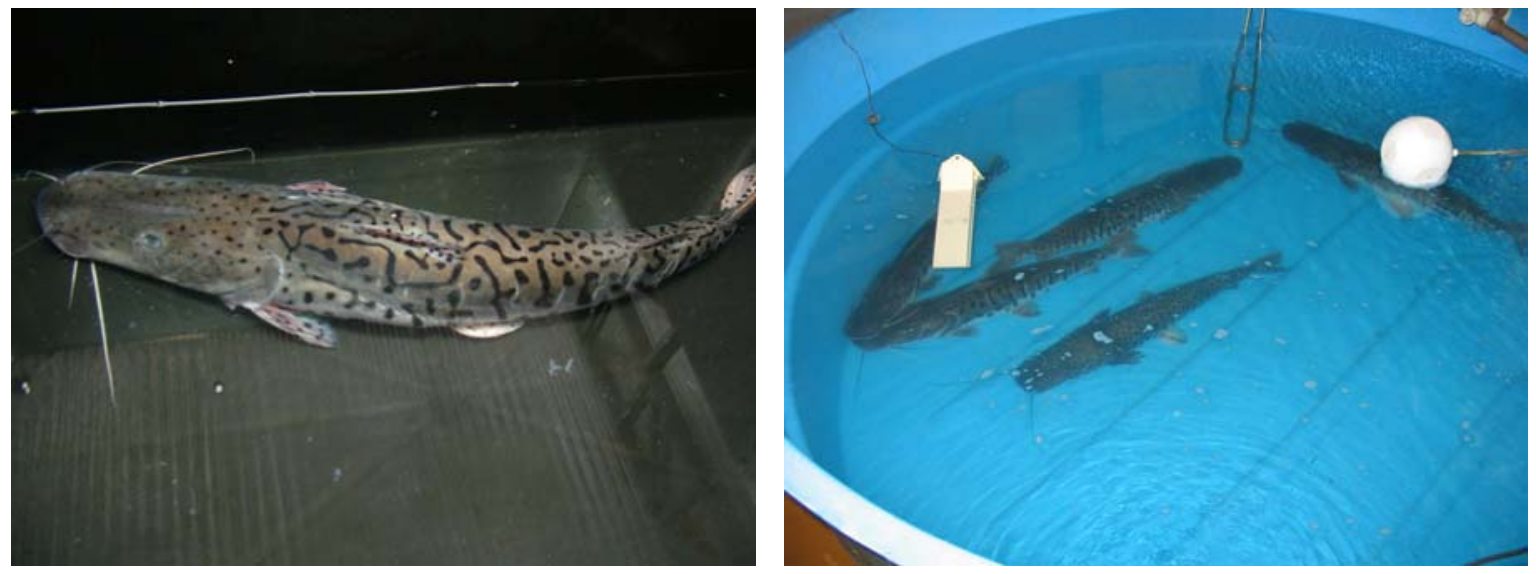

Figura 1 - Peixes (pintados) no tanque do Biotério de Animais Aquáticos do Laboratório de Histofisiologia Evolutiva do Instituto de Ciências Biomédicas - USP

\subsection{COLETA, FIXAÇÃO E PROCESSAMENTO PARA MICROSCOPIA ÓPTICA}

Após 24 horas desde a captura, os animais foram eutanasiados em solução de benzocaína a $50 \mathrm{ppm}$ (diluída em $1 \mathrm{ml}$ de acetona) em solução aquosa, em dosagem excessiva e suficiente para que houvesse completa cessação dos movimentos operculares, e com isto constatação de parada respiratória. Em seguida procedeu-se a abertura da cavidade abdominal por incisão longitudinal ventral na linha média e retirada do trato digestório.

Os órgãos do trato digestório: esôfago, estômago e intestino foram extraídos da cavidade abdominal, dissecados para obtenção das amostras dos segmentos de cada um desses órgãos, lavados em solução salina a 0,9\%, e posteriormente fixados em solução de Bouin, para inclusão em paraplast (Paraplast Tissue Embedding 
Medium - Oxford) e nas soluções de McDowell: formaldeído (obtido a partir do paraformaldeído) a $4 \%$ em solução de glutaraldeído a $1 \%$ em tampão fosfato $0,1 \mathrm{M}$ pH 7,2 (GERRITS, 1983) e formol cálcio de Baker: formaldeído (obtido a partir do paraformaldeído) a $4 \%$ em solução de cloreto de cálcio a 1\% (HERNANDEZBLAZQUEZ et al., 1989) para inclusão em historresina.

As amostras fixadas em Bouin permaneceram no mesmo apenas por 8 horas e foram posteriormente tratadas em álcool $70 \%$, durante várias lavagens, e após foram emblocadas em paraplast. As demais amostras, fixadas em McDowell e em formol cálcio de Baker, foram acondicionadas em refrigerador até o momento de sua inclusão em historresina.

Os segmentos foram então aparados e reduzidos a aproximadamente $1 \mathrm{~mm}$ de tamanho e incluídos em resina histológica Leica Historesin LKB 2218 (Heidelberg, Alemanha), procedendo-se da seguinte forma para as amostras fixadas em McDowell: álcool 70\% durante toda a noite, álcool 95\% por duas horas, solução com $50 \%$ de resina e $50 \%$ de álcool a $95 \%$ por quatro horas, resina a $100 \%$ durante toda a noite. Para inclusão do material utilizou-se resina $100 \%$ na qual adicionou-se 1,5 $\mathrm{ml}$ de endurecedor HISTORESIN 501 para cada $15 \mathrm{ml}$ de resina básica.

O preparo da historresina segue o seguinte protocolo: $50 \mathrm{ml}$ de resina básica, onde acrescentou-se $0,5 \mathrm{~g}$ do ativador, misturando vagarosamente, até a completa dissolução do mesmo. Esta mesma solução infiltradora também foi empregada como base do meio de inclusão.

Foram realizados cortes histológicos de 7 micrômetros de espessura das amostras incluídas em paraplast utilizando-se micrótomo 820 Spencer Microtome e lâminas Leica 818. E das amostras incluídas em historresina, foram feitos cortes com 3 micrômetros de espessura de cada segmento, utilizando-se micrótomo Spencer Lens Co. Microtome com o emprego de navalhas de vidro da marca Leica. Os cortes foram levados a um recipiente contendo água destilada à temperatura ambiente e colhidos em lâminas de vidro Knittel Gläser 76x26 mm. 


\subsection{MÉTODOS DE COLORAÇÃO E DOCUMENTAÇÃO FOTOGRÁFICA}

Para realização do estudo histológico do esôfago, estômago e intestino, as amostras incluídas em paraplast foram coradas utilizando-se a técnica com Hematoxilina e Eosina (HE) (BANCROFT; STEVENS, 1982). Para aquelas incluídas em historresina, as técnicas de coloração utilizadas foram Hematoxilina e Floxina (HF) e também Azul de Toluidina a 1\% em tampão fosfato $\mathrm{pH} 5,0$, para evidenciação do muco ácido, além de evidenciar outras estruturas do tecido em vários tons de azul.

Para identificação de mucopolissacarídeos (glicoconjugados), os cortes foram submetidos às reações histoquímicas seguintes, de acordo com Bancroft e Gamble (2002):

a) ácido periódico-reativo de Schiff (PAS), utilizando Hematoxilina como coloração de fundo, com a finalidade de detecção de muco neutro, corando glicoconjugados neutros em magenta, devido a reação do reativo de Schiff com os grupamentos vic-glicóis.

b) Azul de Alcian (AB) a 1\% em ácido acético a 3\% e pH 2,5 empregando-se Safranina $O$ a $0,1 \%$ para contraste. Com esta reação detecta-se o muco ácido, os quais coram-se em azul intenso.

c) Reação combinada de Ácido periódico-reativo de Schiff (PAS) + Azul de Alcian (AB) para detecção conjunta de mucopolissacarídeos ácidos e neutros, sendo a intensidade da coloração obtida indicadora da proporção entre muco ácido e neutro.

Posteriormente, todo o material foi observado com o auxílio do microscópio óptico OLYMPUS modelo BX60 com câmera modelo AxioCam HCr, marca ZEISS, e obtidas fotomicrografias utilizando-se o programa KS400, 3.4, da marca ZEISS, ano 2000, no Setor de Anatomia do Departamento de Cirurgia da Faculdade de Medicina Veterinária e Zootecnia da USP, São Paulo. 


\section{RESULTADOS}

Os resultados obtidos neste trabalho são descritos abaixo.

\subsection{ESÔFAGO}

O esôfago do Pintado constitui-se de um órgão curto, conectando a parte caudal da cavidade oral ao estômago. Histologicamente, o esôfago apresenta algumas características próprias.

\subsubsection{Mucosa}

A mucosa é constituída por epitélio e lâmina própria e não se observa a camada muscular da mucosa. Apresenta-se pregueada, sendo suas pregas primárias elevadas e longitudinais. Em alguns pontos, a lâmina própria adentra a região da prega, acompanhando seu formato.

\subsubsection{Epitélio}

O epitélio de revestimento encontrado no esôfago de pintado é do tipo pavimentoso estratificado não-queratinizado. Nesse epitélio podem ser identificados três tipos celulares diferenciados, sendo: as epiteliais, as mucosas e as claviformes. 
Descrição dos tipos celulares presentes no epitélio:

a) Células epiteliais: à medida que se aproximam da luz, tornam-se achatadas, com o núcleo alongado, acompanhando o formato celular. Entre elas, existem as superficiais, as intermediárias e as basais, assim descritas:

- superficiais: são células achatadas, localizadas na porção mais superior do epitélio, pavimentando-o em toda sua extensão.

- intermediárias: são células com núcleo ovalado, localizadas entre as células claviformes, na camada média do epitélio.

- basais: são pequenas em relação às demais células do epitélio, possuem núcleo ovalado, formando uma camada junto à membrana basal, se apoiando sobre ela.

b) Células mucosas: são células ovaladas, localizadas superficialmente no epitélio, formando uma camada descontínua, sendo em alguns pontos do epitélio interrompidas por células claviformes. Encontram-se repletas de produto de secreção, o qual preenche quase todo o citoplasma da célula, fazendo com que o núcleo se posicione na base da célula, permanecendo com forma achatada. Utilizando-se os métodos histoquímicos com PAS e Alcian Blue, estas células apresentaram reação positiva, indicando, respectivamente, presença de mucopolissacarídeos neutros e ácidos.

c) Células claviformes: são células grandes, ovaladas, com núcleo central fortemente corado pela hematoxilina e citoplasma corado pela eosina, sendo, portanto, chamadas de células acidófilas, devido à presença de agregado protéico no citoplasma. Localizadas acima das células basais, formando camadas descontínuas. Em alguns pontos elas se estendem entre as células mucosas e atingem a superfície do epitélio. Na região basal do epitélio, existem algumas células que se apresentam com o núcleo maior, sendo circundado por um halo branco, indicando serem células claviformes em diferentes fases de diferenciação celular (Apêndice A, Figuras 4 e 5). 


\subsubsection{Lâmina própria}

Com a ausência da camada muscular da mucosa, a lâmina própria e a túnica submucosa são chamadas coletivamente de lâmina própria da mucosa. A lâmina própria é subdividida em um stratum compactum e um stratum laxum, sendo assim descritos:

- stratum compactum: consiste em uma trama de fibras de tecido conjuntivo denso, contendo feixes de fibras colágenas, estreitamente agrupadas, formando uma lâmina densa denominada stratum compactum.

- stratum laxum: constituído por uma fina camada de tecido conjuntivo frouxo, contendo fibras colágenas, células do tecido adiposo e vasos sangüíneos. Neste stratum laxum, entremeado às células adiposas, encontra-se em alguns locais, feixes nervosos.

Não foram encontradas glândulas esofágicas.

\subsubsection{Camada muscular}

A camada muscular do esôfago é formada por tecido muscular estriado esquelético se distribuindo em duas subcamadas: uma camada interna longitudinal e uma camada externa circular. Trata-se de duas camadas de músculo estriado esquelético, uma vez que apresentam-se multinucleadas, com seus núcleos na periferia e estriações transversais.

Observam-se lojas musculares delimitadas por tecido conjuntivo, com predomínio de fibras colágenas. Não foram observadas fibras musculares lisas.

Artérias e veias podem surgir entre os septos intermusculares. 


\subsubsection{Serosa}

Formada por uma camada de tecido conjuntivo frouxo. Delimitado externamente por uma túnica adventícia.

\subsection{ESTÔMAGO}

O estômago do pintado constitui-se de um órgão em forma de J, distinguindose três regiões neste órgão: cárdica, localizada logo após a região de transição esôfago-gástrica, fúndica, com posição intermediária e a pilórica, sendo a região terminal. Histologicamente, o estômago apresenta características peculiares.

\subsubsection{Mucosa}

A mucosa do estômago é constituída por um epitélio, membrana basal, lâmina própria e apresenta-se marcadamente espessa devido à presença de glândulas gástricas. Em alguns pontos, a mucosa apresenta pregas gástricas largas e simples.

\subsubsection{Epitélio}

O epitélio de revestimento encontrado no estômago é do tipo colunar simples. Nesse epitélio podem ser identificados dois tipos celulares diferenciados, sendo: as células colunares superficiais e as colunares das criptas. Os tipos celulares presentes no epitélio podem ser assim descritos: 
a) Células colunares superficiais: estão presentes na superfície do epitélio, entre as criptas gástricas. São altas, com o núcleo localizado na base da célula e o citoplasma repleto de grânulos de secreção. Estas células apresentaram reação positiva ao método histoquímico com PAS e AB, indicando, portanto, a presença de mucopolissacarídeos neutros e ácidos, respectivamente, no epitélio.

b) Células colunares das criptas: células semelhantes às superficiais, porém mais baixas e apresentando formato hexagonal.

\subsubsection{Criptas gástricas}

A superfície epitelial é interrompida pelas criptas gástricas, depressões, no fundo das quais se abrem as glândulas gástricas. A profundidade destas criptas gástricas é variável de acordo com a região epitelial analisada, sendo mais profundas na região cárdica ou proximal do estômago e em alguns locais apresentam-se mais rasas (Apêndice B, Figura 6). São separadas por tecido conjuntivo, ocorrendo em espaços regulares e, em alguns locais elas se apresentam ramificadas.

\subsubsection{Glândulas gástricas}

Apresentam-se maiores e mais numerosas no segmento proximal do estômago, diminuindo em quantidade e tamanho no sentido caudal (Apêndice $B$, Figura 6). As glândulas são do tipo acinosas ramificadas e encontram-se separadas em lojas por septos de tecido conjuntivo, ricos em fibras colágenas, ocupando toda a lâmina própria, e abrem-se no fundo das criptas gástricas. Formando a parede das glândulas gástricas e a preenchendo foi identificada a célula oxintopéptica, com 
citoplasma acidófilo, repleto de grânulos de secreção visíveis que se coram intensamente pela eosina. O núcleo é arredondado, localizando-se na porção basal da célula e ocorrem em grande quantidade no estômago de pintado.

\subsubsection{Lâmina própria}

A lâmina própria é constituída por um tecido conjuntivo propriamente dito frouxo, altamente vascularizado. Situa-se abaixo da base do epitélio da mucosa, circundando as criptas gástricas e as glândulas gástricas, contendo grande quantidade de fibras colágenas. As fibras colágenas se dirigem em direção ao epitélio de revestimento, sustentando-o e acompanhando as glândulas gástricas, entrecruzando-se e envolvendo cada glândula numa rede, suportando-as. Os capilares estão dispostos perpendicularmente à superfície entrando em contato com as glândulas gástricas, formando um plexo abaixo do epitélio.

\subsubsection{Muscular da mucosa}

A camada muscular da mucosa apresenta-se como faixas descontínuas de fibras musculares lisas, localizadas abaixo da lâmina própria, interrompidas por tecido conjuntivo frouxo. 


\subsubsection{Submucosa}

A submucosa localiza-se entre a lâmina própria e a camada muscular, sendo constituída por uma extensa região contendo tecido conjuntivo frouxo, rico em fibras colágenas. Estão também presentes artérias, veias e células adiposas ao longo de seu comprimento. Contém faixas de fibras musculares não organizadas, dispostas ao longo da região distal do estômago.

\subsubsection{Camada muscular}

A camada muscular do estômago é formada por duas subcamadas de tecido muscular: uma camada circular interna e uma camada longitudinal externa. A camada circular interna é composta por fibras musculares lisas e a camada longitudinal externa, composta por fibras de músculo estriado esquelético. O tecido conjuntivo, rico em fibras colágenas, forma septos entre as células musculares e as separa em feixes.

$\mathrm{Na}$ porção distal do estômago encontram-se faixas concentradas de músculo estriado, indicando a presença do esfíncter pilórico nesta região.

\subsubsection{Serosa}

Formada por epitélio pavimentoso simples e uma camada de tecido conjuntivo frouxo, encontrando-se artérias e veias em sua espessura. 


\subsection{INTESTINO}

O intestino do pintado constitui-se de três regiões distintas e denominadas: intestino proximal, intestino médio e intestino distal ou reto. A parede intestinal é pouco espessa quando comparada à do estômago.

\subsubsection{Descrição macroscópica}

Para fins de coleta, as regiões intestinais foram divididas e denominadas: intestino proximal, intestino médio e intestino distal ou reto. Esta divisão foi realizada baseando-se na localização das mesmas e em sua distribuição macroscópica por nós observadas na cavidade celomática do pintado (Figura 2). O intestino proximal inicia-se na junção entre o intestino e o estômago e compreende três segmentos denominados de segmento 1, 2 e 3, respectivamente. Logo após esta junção com o estômago, o intestino proximal inicia-se e compreende uma curvatura, ao redor do estômago, estando em contato com o fígado e a vesícula biliar. Consideramos esta curvatura como sendo a primeira alça intestinal (A1). Notamos que esta região, ou seja, o intestino proximal, sofre duas contrições, as quais utilizamos para subdividi-lo e tomar os segmentos 1, 2 e 3. Após a passagem do intestino proximal sobre a vesícula biliar, nota-se uma nova constrição e redução do diâmetro do intestino delimitando o início do segmento seguinte. A partir deste ponto, denominamos intestino médio, portanto iniciando-se a segunda alça intestinal (A2), a qual se localiza entre a $3^{a}$ constrição e a $1^{a}$ circunvolução. $O$ intestino médio apresenta o diâmetro uniforme e mais delgado que o intestino proximal, sendo enovelado, à exceção dos seus primeiros três segmentos, pertencentes à A2. Dividimos esta região intestinal em oito segmentos, em média, abrangendo mais duas outras alças intestinais (A3 e A4), as quais se apresentam mais acentuadas e contorcidas, sendo denominadas de "circunvoluções". A primeira circunvolução, correspondente a A3, compreende os segmentos 4 e 5 . A segunda circunvolução (A4), engloba os 
segmentos 6, 7 e 8. Toda esta região permanece em contato com a bexiga natatória. A última região considerada foi denominada de intestino distal ou reto. Trata-se de uma região retilínea que inicia-se após o término da $2^{a}$ circunvolução e representa a última alça intestinal (A5). Foram coletados quatro segmentos do intestino distal ou reto, denominados 1, 2, 3 e 4. O reto está em contato com a bexiga natatória e sua trajetória se faz entre as duas gônadas, direita e esquerda, até desembocar no ânus. (Figura 3 e Quadro 1). 


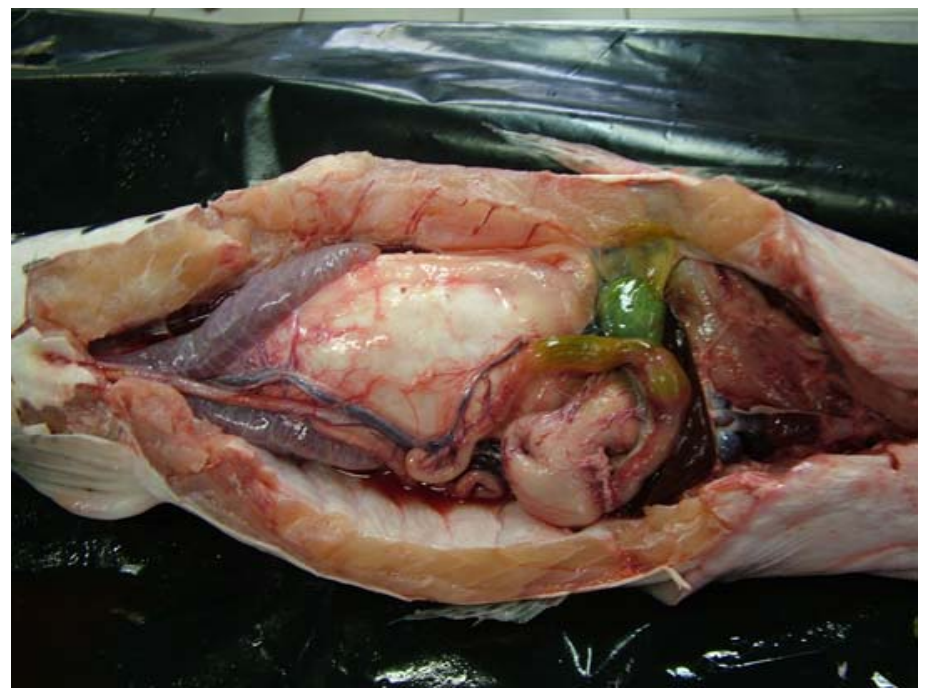

Figura 2 - Arranjo do trato digestório na cavidade celomática do pintado, mostrando a localização dos órgãos componentes e sua sintopia. Visão ventral

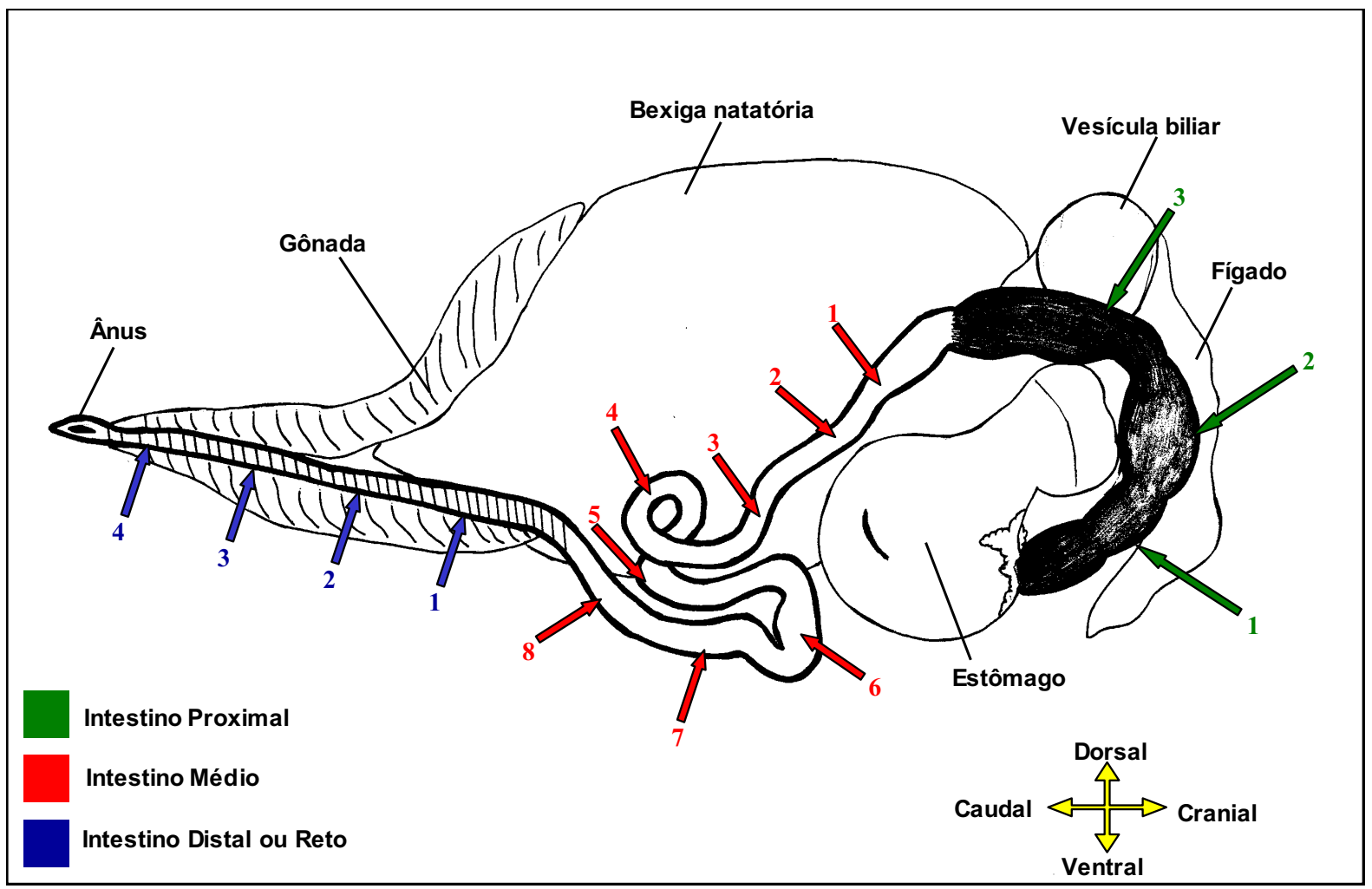

Intestino Proximal: segmentos 1 - $3 \rightarrow$ Alça 1

Intestino Médio: segmentos 1 - $3 \rightarrow$ Alça 2; segmentos 4 e $5 \rightarrow$ Alça 3; segmentos 6 - $8 \rightarrow$ Alça 4 Intestino Distal ou Reto: segmentos 1 - $4 \rightarrow$ Alça 5

Figura 3 - Desenho esquemático das regiões intestinais, baseado em um espécime de $P$. coruscans 


\begin{tabular}{|c|c|c|c|c|}
\hline $\begin{array}{c}\text { Regiões } \\
\text { Intestinais }\end{array}$ & Alça & $\begin{array}{c}\text { Limite } \\
\text { Anatômico }\end{array}$ & Segmentos & $\begin{array}{c}\text { Limite } \\
\text { Anatômico }\end{array}$ \\
\hline \multirow{8}{*}{$\begin{array}{l}\text { Intestino } \\
\text { Proximal }\end{array}$} & \multirow[t]{8}{*}{ A1 } & \multirow{3}{*}{$\begin{array}{c}\text { Anterior ou } \\
\text { proximal: } \\
\text { estômago }\end{array}$} & 1 & $1^{\mathrm{a}}$ constrição \\
\hline & & & & 2а \\
\hline & & & 2 & 2 comstriçau \\
\hline & & & 3 & $3^{a}$ constrição \\
\hline & & Posterior ou & & \\
\hline & & distal: final da & & \\
\hline & & primeira & & \\
\hline & & curvatura & & \\
\hline \multirow{9}{*}{$\begin{array}{l}\text { Intestino } \\
\text { Médio }\end{array}$} & \multirow[t]{4}{*}{$\mathrm{A} 2$} & \multirow{4}{*}{$\begin{array}{c}\text { Entre a } 3^{a} \\
\text { constrição e a } \\
1^{\text {a }} \\
\text { circunvolução }\end{array}$} & 1 & $1^{\circ}$ terço \\
\hline & & & 2 & $2^{\circ}$ terço \\
\hline & & & 3 & $3^{\circ}$ terço \\
\hline & & & & \\
\hline & \multirow[t]{2}{*}{ A3 } & \multirow{2}{*}{$1^{a}$} & 4 & $1^{a}$ metade \\
\hline & & & 5 & $2^{a}$ metade \\
\hline & \multirow[t]{3}{*}{ A4 } & \multirow{3}{*}{$2^{\mathrm{a}}$} & 6 & $1^{\circ}$ terço \\
\hline & & & 7 & $2^{\circ}$ terço \\
\hline & & & 8 & $3^{\circ}$ terço \\
\hline \multirow{6}{*}{$\begin{array}{c}\text { Intestino Distal } \\
\text { ou Reto }\end{array}$} & \multirow[t]{6}{*}{ A5 } & \multirow{4}{*}{$\begin{array}{c}\text { Anterior: } \\
\text { segmento } \\
\text { retilíneo após } \\
\text { término da } 2^{\mathrm{a}} \\
\text { circunvolução }\end{array}$} & 1 & $1^{\circ}$ quarto \\
\hline & & & 2 & $2^{\circ}$ quarto \\
\hline & & & 3 & $3^{\circ}$ quarto \\
\hline & & & 4 & $4^{\circ}$ quarto \\
\hline & & Posterior: & & \\
\hline & & ânus & & \\
\hline
\end{tabular}

Quadro 1 - Subdivisão do intestino do pintado em regiões intestinais, suas alças e limites anatômicos - São Paulo - 2006 


\subsubsection{Descrição Microscópica}

O intestino do pintado subdivide-se em regiões proximal, média e distal, com características microscópicas particulares, as quais serão descritas abaixo.

\subsubsection{Intestino Proximal}

Histologicamente, o intestino proximal apresenta as características seguintes.

\subsection{Mucosa}

A mucosa do intestino proximal é constituída por um epitélio, membrana basal e lâmina própria. A lâmina própria, juntamente com o epitélio se projetam na luz do intestino formando numerosos e longos vilos intestinais, que, nesta porção proximal, apresentam-se em forma de folha.

\subsection{Epitélio}

O epitélio de revestimento encontrado é do tipo colunar simples. Nesse epitélio podem ser identificados dois tipos celulares diferenciados, sendo: as células epiteliais colunares e as células caliciformes (Apêndice C, Figura 8). Os tipos celulares presentes no epitélio podem ser assim descritos: 
a) Células epiteliais colunares: também chamadas de células absortivas ou enterócitos. É o tipo celular mais numeroso. Estão presentes na superfície do epitélio, seu núcleo, de formato alongado, situa-se próximo à região basal das células.

b) Células caliciformes: são células em forma de cálice, com citoplasma repleto de produto de secreção. Localizam-se ao longo da superfície epitelial, ocorrendo entre os enterócitos. Poucas são observadas no intestino proximal, aumentando em número no sentido caudal (Apêndice B, Figura 7).

Há a presença de numerosos linfócitos intraepiteliais, com núcleos circulares pretos, no epitélio (Apêndice C, Figura 8B). São encontrados em maior quantidade no intestino proximal, nos primeiros segmentos e após esta região intestinal, são observados de forma isolada ao longo dos demais segmentos intestinais.

\subsection{Lâmina própria}

A lâmina própria é constituída por um tecido conjuntivo propriamente dito frouxo, rico em fibras colágenas, altamente vascularizado e situa-se abaixo da base do epitélio da mucosa, estendendo-se para dentro das vilosidades intestinais. Não foi observada a camada muscular da mucosa.

\subsection{Submucosa}

A submucosa localiza-se entre a lâmina própria e a camada muscular, sendo constituída por tecido conjuntivo frouxo, rico em fibras colágenas, que se entremeiam na lâmina própria, acompanhando o formato dos vilos intestinais. Não há uma separação nítida entre esta e a lâmina própria. 


\subsection{Camada muscular}

A camada muscular do intestino proximal é formada por duas subcamadas de tecido muscular: uma camada circular interna e uma camada longitudinal externa. Ambas são compostas por fibras musculares lisas.

\subsection{Serosa}

Formada por epitélio pavimentoso simples e uma camada muito espessa constituída de tecido conjuntivo denso, rico em fibras colágenas, encontrando-se artérias e veias em sua espessura.

\subsubsection{Intestino Médio}

As características histológicas do intestino médio seguem. 


\subsection{Mucosa}

A mucosa do intestino médio é constituída por um epitélio, membrana basal e lâmina própria. A lâmina própria, juntamente com o epitélio se projetam na luz do intestino formando numerosos e longos vilos intestinais.

\subsection{Epitélio}

O epitélio de revestimento encontrado é do tipo colunar simples. A borda do epitélio apresenta cutícula estriada. Nesse epitélio podem ser identificados dois tipos celulares diferenciados, sendo: as células epiteliais colunares e as células caliciformes. Na porção distal do intestino médio observam-se gotículas de gordura presentes entre as células caliciformes. Os tipos celulares presentes no epitélio podem ser assim descritos:

a) Células epiteliais colunares: também chamadas de células absortivas ou enterócitos. É o tipo celular mais numeroso. Estão presentes na superfície do epitélio, seu núcleo, de formato alongado, situa-se próximo à região basal das células e apresenta um nucléolo evidente.

b) Células caliciformes: são células em forma de cálice, com citoplasma repleto de produto de secreção. Localizam-se ao longo da superfície epitelial, ocorrendo entre os enterócitos. Poucas são observadas no início do intestino médio, aumentando em número no sentido caudal (Apêndice $\mathrm{C}$, Figura 9A e Apêndice D, Figura 10A). Apresentam reação positiva ao método histoquímico com PAS e também com AB.

Linfócitos intraepiteliais são encontrados no epitélio, porém, em menor quantidade se comparado com os segmentos do intestino proximal, onde aparecem com maior freqüência. 
Nas porções média e distal do intestino médio, encontram-se macrófagos intraepiteliais dispostos de forma isolada ou em agrupamentos, dependendo da região considerada do epitélio. Seu citoplasma apresenta-se eosinofílico e o núcleo, central, fortemente corado pela hematoxilina (Apêndice C, Figura 9B e Apêndice D, Figura 11B).

São encontradas no epitélio glândulas intestinais em toda extensão do intestino médio, as quais também são vistas, em menor quantidade, no intestino distal ou reto. Trata-se de glândulas tubulares ramificadas, circundadas por tecido conjuntivo, e contém células mucosas PAS + AB positivas (Apêndice D, Figura 11A).

\subsection{Lâmina própria}

A lâmina própria é constituída por um tecido conjuntivo propriamente dito frouxo, rico em fibras colágenas, altamente vascularizado e situa-se abaixo da base do epitélio da mucosa, estendendo-se para dentro das vilosidades intestinais.

\subsection{Submucosa}

A submucosa localiza-se entre a lâmina própria e a camada muscular, sendo constituída por tecido conjuntivo frouxo, rico em fibras colágenas, que se entremeiam na lâmina própria, acompanhando o formato dos vilos intestinais. 


\subsection{Camada muscular}

A camada muscular do intestino médio é formada por duas subcamadas de tecido muscular: uma camada circular interna e uma camada longitudinal externa. Ambas são compostas por fibras musculares lisas. Na porção média desta região intestinal a camada interna apresenta fibras dispostas transversalmente e na camada externa, longitudinalmente. Na porção distal, ocorre uma inversão na disposição destas fibras musculares.

\subsection{Serosa}

Formada por uma camada espessa constituída de tecido conjuntivo denso, rico em fibras colágenas, encontrando-se artérias e veias em sua espessura. $O$ epitélio encontrado nesta camada serosa é do tipo pavimentoso simples. Apresentase um pouco mais espessa na porção distal do intestino médio.

\subsubsection{Intestino Distal ou Reto}

Histologicamente, o intestino proximal apresenta as características seguintes. 


\subsection{Mucosa}

A mucosa do intestino distal ou reto é constituída por um epitélio, membrana basal e lâmina própria. A lâmina própria, juntamente com o epitélio se projetam na luz do intestino formando numerosos vilos intestinais.

\subsection{Epitélio}

O epitélio de revestimento encontrado é do tipo colunar simples e apresentase com borda em escova (Apêndice E, Figura 12A). Nesse epitélio podem ser identificados dois tipos celulares diferenciados, sendo: as células epiteliais colunares e as células caliciformes. Observa-se que o epitélio encontrado é mais baixo (Apêndice E, Figura 13) e as células mais globosas. Na porção distal do reto observam-se gotículas de gordura presentes no epitélio. Os tipos celulares presentes neste epitélio podem ser assim descritos:

a) Células epiteliais colunares: também chamadas de células absortivas ou enterócitos. É o tipo celular mais numeroso. Estão presentes na superfície do epitélio, seu núcleo, de formato alongado, situa-se próximo à região basal das células e apresenta um nucléolo evidente.

b) Células caliciformes: são células em forma de cálice, com citoplasma repleto de produto de secreção. Localizam-se ao longo da superfície epitelial, ocorrendo entre os enterócitos (Apêndice E, Figura 12). No intestino distal ou reto, são observadas em maior quantidade do que no intestino médio, no segmento intestinal imediatamente anterior, e estas aumentam em número no sentido caudal (Tabela 1). Apresentam reação positiva ao método histoquímico com PAS e com AB. 
Tabela 1 - Freqüência de células caliciformes nos segmentos das regiões intestinais do pintado segundo o tipo de mucosubstâncias coradas pelos métodos de coloração histoquímicos - São Paulo - 2006

Segmento $\underline{\text { PAS }} \quad \underline{A B} \quad \underline{P A S+A B}$

\section{Intestino Proximal}

$\begin{array}{llll}1 & +- & + & + \\ 2 & +- & + & + \\ 3 & +- & + & +- \\ 4 & +- & ++ & +-\end{array}$

\section{$\underline{\text { Intestino Médio }}$}

2

$+-$

$+$

$++$

$++$

$++$

$++$

$++$

$++$

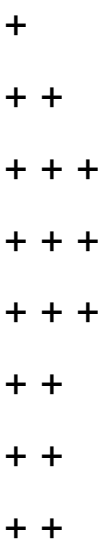

$+$

$+$

$+++$

$+++$

$++$

$++$

$++$

$++$

\section{$\underline{\text { Intestino Distal }}$}

$\begin{array}{llll}1 & +- & ++ & ++ \\ 2 & + & ++ & ++ \\ 3 & + & + & ++\end{array}$

AB, Alcian Blue; PAS, Periodic Acid of Schiff; (+ -) pouquíssimo freqüente; (+) moderadamente freqüente; $(++)$ freqüente; $(+++)$ intensamente freqüente 


\subsection{Lâmina própria}

A lâmina própria é constituída por um tecido conjuntivo propriamente dito frouxo, rico em fibras colágenas, altamente vascularizado e situa-se abaixo da base do epitélio da mucosa, estendendo-se para dentro das vilosidades intestinais.

\subsection{Submucosa}

A submucosa localiza-se entre a lâmina própria e a camada muscular, sendo constituída por tecido conjuntivo denso não-modelado, rico em fibras colágenas, que se entremeiam na lâmina própria, acompanhando o formato dos vilos intestinais.

\subsection{Camada Muscular}

A camada muscular do intestino distal ou reto é formada por duas subcamadas de tecido muscular: uma camada circular interna e uma camada longitudinal externa. Ambas são compostas por fibras musculares lisas. Nesta região, estas duas camadas de musculatura encontram-se separadas uma da outra por uma faixa de tecido conjuntivo frouxo, mais espesso do que o encontrado em outras regiões intestinais. 


\subsection{Serosa}

Formada por uma camada muito espessa constituída de tecido conjuntivo denso, rico em fibras colágenas, encontrando-se artérias e veias em sua espessura. O epitélio encontrado nesta camada serosa é do tipo pavimentoso simples. Apresenta-se um pouco mais espessa nas porções média e distal do reto. 


\section{DISCUSSÃO}

A estrutura histológica do trato digestório do $P$. coruscans é, no aspecto geral, semelhante à de outros peixes teleósteos, contudo, apresenta algumas características peculiares.

Em Pseudoplatystoma coruscans o esôfago apresenta-se como um órgão tubular curto de diâmetro relativamente uniforme, semelhante ao encontrado em Salmo trutta (BURNSTOCK, 1959) e em Pimelodus maculatus (GODINHO, 1967) diferindo-se de alguns poucos nos quais o esôfago apresenta-se longo, como em Dorosoma cepedianum (SCHMITZ; BAKER, 1969), Chelmon rostratus (TAN; TEH, 1974), Polypterus senegalus, (MAGID, 1975) e Plecostomus commersonii (BORGES, 1981).

Possui paredes elásticas, permitindo um aumento no seu diâmetro durante a deglutição do alimento. Internamente sua mucosa apresenta pregas longitudinais, as quais possibilitam maior extensibilidade ao órgão, facilitando a condução do alimento da cavidade oral ao estômago. Tal fato também ocorre em Cirrhinus mrigala (SINHA, 1979).

Quanto ao tipo de epitélio encontrado no esôfago de Pseudoplatystoma coruscans, o pavimentoso estratificado não-queratinizado, também está presente em Scomberomorus maculatus (ALVES, 1969) e em Pimelodus maculatus (GODINHO et al., 1970).

O epitélio do esôfago de pintado, do tipo pavimentoso estratificado, juntamente à secreção abundante de muco proporciona proteção adicional contra o atrito de alimentos com alto poder abrasivo, tal qual ocorre em Prochilodus scrofa, que se alimentam de lodo e algas Diatomae, organismos ricos em sílica (HERNANDEZ-BLAZQUEZ, 1986).

As células mucosas presentes em grande quantidade no esôfago do pintado sugerem que o órgão está morfologicamente preparado para se proteger contra a ação abrasiva do alimento. Estas células se encontram já desenvolvidas logo no $3^{\circ}$ 
dia após a eclosão das larvas do pintado (MANGETTI, 2006). O muco produzido por estas células mucosas lubrifica a superfície do órgão e protege-o contra abrasão e lesão no epitélio provocada pela passagem de alimentos (ANDERSON, 1986; GALVÃO et al., 1997; GODINHO, 1970). Sendo assim, a passagem de presas vivas é facilitada pelo muco produzido que lubrifica as paredes do esôfago e pela organização das fibras do tecido conjuntivo denso, o stratum compactum, que reforça a sua parede (BURNSTOCK, 1959), provavelmente evitando rupturas e perfurações.

Além da função protetora, a secreção do muco está associada a adesão entre as partículas de alimento, as quais são unidas para facilitar o seu transporte no trato digestório (CHAUDRY; KHANDELWAL, 1961). O muco ácido está associado a uma proteção mais eficiente do epitélio (REIFEL; TRAVILL, 1977), sendo encontrado no epitélio do pintado em maior quantidade que o muco neutro. Sendo assim, essa secreção de muco ácido sugere a capacidade do peixe em produzir muco aglutinante capaz de agregar partículas alimentares e ao mesmo tempo proteger a mucosa. Por outro lado, a função protetora conferida à superfície esofágica em Leporinus friderici e L. taeniofasciatus, segundo Albrecht et al. (2001) deve-se primeiramente às diversas camadas celulares existentes no epitélio e, em segundo plano, à secreção mucosa.

A presença em grande quantidade de células claviformes no epitélio do esôfago de pintado, que são células de defesa, do "sistema de alarme" do organismo (GODINHO, 1970), garantem a proteção do esôfago, ao serem estimuladas, caso haja uma lesão no órgão, provocada por algum espinho presente na presa (Apêndice A, Figuras 4 e 5).

As células claviformes estão presentes quando o epitélio do órgão está sendo lesionado. Em peixes, é comum a existência de células mucosas na pele e, havendo dano mecânico à pele, estas células liberam uma substancia de alarme ("Schreckstoff") na epiderme (IRVING, 1996). No epitélio do esôfago do pintado foram encontradas células claviformes em diferentes fases de desenvolvimento, indicando que está havendo demanda na produção destas células, para acionar o 
sistema de alarme do organismo para se defender de alguma possível lesão a que o esôfago deste animal possa estar sendo submetido.

São as células claviformes e o sistema de fibras colágenas que fazem com que o esôfago seja um órgão capaz de suportar os "ataques" e a pressão da alimentação com presas vivas. Promovem a defesa e sustentação do órgão, constituindo um sistema de reforço do esôfago.

O pintado possui uma trama de fibras colágenas considerável na lâmina própria, devido ao tipo de alimentação que possui, se alimentando de peixes, presas vivas, que podem lesionar o esôfago. A maior quantidade de fibras colágenas no tecido conjuntivo denso do esôfago e do estômago promovem elasticidade maior ao órgão, permitindo a esta espécie engolir alimentos grandes e armazenar mais alimentos no estômago (ALBRECHT et al., 2001). Além disso, promovem sustentação ao esôfago, permitindo a este órgão suportar a pressão do alimento deglutido.

A ausência da muscular da mucosa ocorrendo no trato digestório é também relatado em outras espécies tal como em Leporinus friderici e L. taeniofasciatus (ALBRECHT et al., 2001), Poecilia reticulata (HALE, 1965) e em Prochilodus sp. (KESSLER, 1979). Usualmente a muscular da mucosa auxilia os movimentos das pregas, as quais misturam o bolo alimentar, facilitando a mistura do alimento à secreção das glândulas gástricas no estômago e a absorção no intestino. Esta ausência parece ser compensada pelas duas espessas camadas musculares e pela presença marcante de fibras elásticas (ALBRECHT et al., 2001).

Não foram encontradas glândulas esofágicas em pintado, discordando dos achados em outros peixes, por alguns autores (DOMITROVIC; MOREIRA, 1984; EZEASOR, 1984; SCHIMITZ; BAKER, 1969).

A camada muscular do esôfago de pintado não apresenta fibras de músculo liso, possuindo apenas musculatura estriada esquelética, distribuindo-se em duas subcamadas, sendo interna longitudinal e outra externa circular. O esôfago desta espécie está submetido constantemente á pressão devido a deglutição de presas vivas e, sendo um órgão curto e que apresenta uma constrição, antes de desembocar no estômago, necessita de uma musculatura reforçada e que apresente 
uma capacidade de força e de contração rápida, o que justifica a presença apenas da musculatura estriada esquelética. A musculatura lisa não se faz necessária neste órgão, uma vez que esta apresenta um processo de contração lento, demandando maior tempo para contrair $e$ isto não contribuiria para a função protetora desempenhada pelo esôfago, sendo o primeiro órgão capaz de promover estrangulamento da presa, conferida por sua vigorosa e potente contração muscular.

Quanto ao estômago de pintado, a túnica mucosa consiste em epitélio colunar simples com núcleo basal, membrana basal, lâmina própria e glândulas gástricas.

$\mathrm{Na}$ superfície epitelial do estômago de pintado são encontradas células colunares superficiais secretoras de mucopolissacarídeos ácidos e neutros, indicados por reação positiva ao método histoquímico com $A B$ e PAS, respectivamente. Em peixes, a secreção de mucopolissacarídeos ácidos e neutros encontrados na superfície epitelial do estômago provavelmente está relacionada ao movimento de fluidos e à absorção de substratos, respectivamente. Além disso, os mucopolissacarídeos secretados pelas células epiteliais parecem ser importantes para a proteção da parede do órgão e inibição contra microorganismos e, ainda, estão envolvidos em digestão enzimática de alimentos, funções absortivas e lubrificação do trato digestório (DÍAZ et al., 2003).

As glândulas gástricas, formadas por um único tipo de célula glandular e localizadas ao longo do estômago em pintado, são mais numerosas na porção cranial do órgão, tal qual acontece em Engraulis anchoita (DÍAZ et al., 2003) (Apêndice B, Figura 6). Assim como em outros peixes teleósteos, as células das glândulas são conhecidas como oxintopépticas, porque é geralmente atribuído a elas as funções das células oxínticas e das células principais dos mamíferos, relacionadas á síntese de ácido e pepsinogênio (GARCÍA HERNÁNDEZ et al., 2001). A maior quantidade das glândulas nessa região mais proximal do estômago em pintado pode estar relacionado a uma demanda maior na produção de secreção capaz de digerir proteínas, uma vez que este peixe, se comportando como um carnívoro voraz, deva estar se alimentando maciçamente de outros peixes ou alimento rico em proteínas. 
É geralmente aceito que as células glandulares gástricas em peixes sintetizam ambos pepsinogênio e ácido (SMITH, 1989) e que os mucopolissacarídeos neutros podem desempenhar um efeito protetor à mucosa contra a alta acidez do conteúdo estomacal (SCOCCO; CECCARELLI,; MENGHI,1996; MORRISON; WRIGHT, 1999). A secreção mucosa das glândulas gástricas poderia impedir partículas grosseiras de passar facilmente pelo trato digestório e a musculatura estriada pode promover regurgitação voluntária, semelhante ao sugerido por Al-Hussaini e Kholy (1953).

Do ponto de vista histofisiológico, o intestino de teleósteos é dividido em três segmentos: proximal, médio e distal (NOAILLAC-DEPEYRE; GAS, 1974, 1976, 1979; STROBAND; VAN DER VEEN, 1981).

A mucosa do intestino proximal é constituída por um epitélio, membrana basal e lâmina própria. A lâmina própria, juntamente com o epitélio se projetam na luz do intestino formando numerosos e longos vilos intestinais, os quais ocorrem em abundância nesta região por estarem associados ao processo de absorção de nutrientes.

Os linfócitos intraepiteliais levam informações recebidas dos antígenos para outras regiões do tubo digestório e, provavelmente, também para outros órgãos através do sangue e da linfa (JUNQUEIRA; CARNEIRO, 1999). Foram encontrados linfócitos intraepiteliais infiltrados no espaço intercelular de todos os segmentos do intestino proximal de pintado e isto sugere evidência morfológica que neste local deve estar ocorrendo um processo imunológico (Apêndice C, Figura 8B). Após esta região, os linfócitos são observados de forma isolada ao longo do intestino.

No epitélio do intestino proximal do pintado foram encontrados macrófagos intraepiteliais. Estes macrófagos foram identificados nos segmentos do intestino médio nos espaços intraepiteliais (Apêndice C, Figura 9B), semelhantemente ao descrito por Nachi (1988), o qual o denominou de célula fagocítica intraepitelial. Foram encontradas características em comum com a célula fagocítica descrita em Prochilodus scrofa (NACHI, 1988), tais como: o local em que foram encontrados, podendo também ser observado em menores proporções em diferentes segmentos intestinais, além de o material fagocitado apresentar-se também com granulação 
intensamente PAS positiva (Apêndice D, Figura 11B). Nachi (1988) empregou ainda a técnica da fosfatase ácida nestas estruturas, para a qual apresentaram-se com reação positiva, sugerindo que os grânulos contidos na célula fagocítica intraepitelial são lisossomos (BANCROFT; STEVENS, 1982).

Uma função atribuída aos macrófagos em peixes, seria a de apresentador de antígenos, pois foi constatada a presença de determinantes antigênicos para ferritina e bactéria Vibrio anguillarum, na superfície externa de macrófagos intraepiteliais do intestino de Cyprinus carpio (ROMBOUT; VAN DEN BERG, 1989). Este papel imunológico desempenhando pelos macrófagos em peixes é semelhante ao que ocorre nas células $\mathrm{M}$ de mamíferos, quanto a captura e apresentação de antígenos aos tipos celulares especializados na defesa do organismo e possível elaboração de substâncias quimiotáticas. Estas células $M$ dos mamíferos são consideradas células epiteliais especializadas e estão presentes em epitélios associados aos folículos linfóides e placas de Peyer (BOCKMAN; COOPER, 1973).

Os macrófagos também estão envolvidos com a fagocitose de macromoléculas ou de pedaços de citoplasma de enterócitos, conforme sugerido por Rombout et al. (1985). Existe um processo de transferência de fagolisossomos contendo proteínas, para o macrófago, o qual se encarrega de processar a digestão destas macromoléculas, com isso liberando os enterócitos para a absorção de mais proteínas (NACHI, 1993). A presença destes macrófagos também pode indicar uma possível agressão no epitélio absortivo do segmento intestinal no qual estes são encontrados, provocando uma migração de macrófagos para esta região, devido a irritação mecânica local da mucosa ou ao aumento da pressão local.

A presença de linfócitos e macrófagos intraepiteliais indica a existência de um processo celular que atua como barreira celular de defesa, provavelmente como componente imunológico no intestino do pintado.

No intestino médio de pintado, em toda sua extensão, são encontradas glândulas intestinais, constituídas por enterócitos e células caliciformes PAS e Alcian Blue positivas (Apêndice D, Figura 11A), também encontradas em Gadus morhua (BISHOP; ODENSE, 1966) e em Prochilodus scrofa (NACHI, 1988). A função e distribuição destas glândulas é motivo de controvérsia e sua existência já chegou a 
ser refutada por Vega-Velez (1972). Entretanto, estas estruturas foram também identificadas em espécies carnívoras da família Gadidae (GEISTDOERFER, 1981), porém não foram encontradas evidências de atividade secretora nestas glândulas. Por outro lado, em Prochilodus scrofa as glândulas intestinais encontradas são bem desenvolvidas e numerosas com muitas células mucosas, sugerindo considerável secreção mucosa. No pintado, as glândulas intestinais são tubulares ramificadas, encontradas na lâmina própria, apresentando grande faixa de tecido conjuntivo entre elas e ocorrem em quantidade bem menor se comparado ao encontrado em Prochilodus scrofa, podendo-se inferir que sua secreção mucosa, nesta espécie, não tenha considerável papel no processo digestivo.

A partir do terceiro segmento do intestino médio, nota-se, no epitélio do pintado, aumento no número de células caliciformes coradas pelo método de PAS e também com o Alcian Blue (Apêndice D, Figura 10A). Estes métodos histoquímicos empregados revelam que as células caliciformes possuem grânulos com reação positiva para glicoconjugados neutros e ácidos. Estes resultados são semelhantes ao encontrado em outros peixes (CLARKE; WITCOMB, 1980; SANTOS; MENDES; NEPOMUCENO, 1979; TAN; TEH, 1974).

No intestino distal ou reto do pintado, observa-se epitélio com cutícula estriada mais baixa do que o encontrado nos segmentos anteriores (Apêndice $E$, Figura 13). Existe correlação entre a altura da borda estriada epitelial e a capacidade absortiva do epitélio intestinal em peixes (KUPERMAN; KUZ'MINA, 1994). Isto significa que o epitélio dessa região intestinal no pintado apresenta menor superfície absortiva e, portanto, menor superfície de captação e absorção de macromoléculas. Este comportamento do epitélio nesta região é justificável, uma vez que o reto constitui-se de um local onde ocorre absorção de água e eletrólitos. Em comparação ao intestino proximal, nestes últimos segmentos intestinais observa-se maior quantidade de células caliciformes, o que confere lubrificação ao bolo alimentar que chega até esse ponto bastante desidratado. 


\section{CONCLUSÕES}

Os resultados obtidos com a metodologia empregada permitem as seguintes conclusões:

1 - o esôfago do pintado é uma estrutura com grande reforço de tecido conjuntivo e apresenta intensa presença de células claviformes, o que indica ser este um órgão sujeito a lesões e lacerações;

2 - a secreção mucosa do estômago de pintado é mista, constituindo-se de muco ácido e neutro, e possui grande quantidade de glândulas oxintopépticas, indicando processos digestivos intensos de natureza química e enzimática, provavelmente devido à sua dieta carnívora;

3 - no pintado, a estrutura intestinal é semelhante à de outros peixes teleósteos carnívoros. A presença de macrófagos intraepiteliais, como em outros peixes, pode sugerir o transporte e degradação intraepitelial de proteínas. 


\section{REFERÊNCIAS}

ALBRECHT, M. P.; FERREIRA, M. F. N.; CARAMASCHI, E. P. Anatomical features and histology of the digestive tract of two related neotropical omnivorous fishes (Characiformes; Anostomidae). Journal of Fish Biology, v. 58, p. 419-430, 2001.

AL-HUSSAINI, A. H. On the functional morphology of the alimentary tract of some fish in relation to differences in their feeding habits. I. Anatomy and Histology. Journal of Microscopical Science, v. 90, p. 109-140, 1949.

AL-HUSSAINI, A. H. The anatomy and histology of the alimentary tract of the bottonfeeder (Mulloides airoflama). J. Morphol., v. 78, p. 121-153, 1946.

AL-HUSSAINI, A. H.; KHOLY, A. A. On the functional morphology of the alimentary tract of some omnivorous fish. Proc. Egypt. Acad. Sci., v. 4, p. 17-39, 1953.

ALVES, M. I. M. Morfologia do aparelho digestivo do pargo (Lutjanus purpureus poey). Arquivos de Ciência Mar, v. 11, p. 147-151, 1971.

ALVES, M. I. M. Sobre o trato digestivo da serra, Scomberomorus maculatus. Arquivos de Ciência Mar, v. 9, p. 167-171, 1969.

ANDERSON, T. A. Histological and cytological structure of the gastrointestinal tract of the luderick, Girella tricuspidata (Pisces, Kyphosidae), in relation to diet. European Journal of Morphology, Liss, v. 190, p. 109-119, 1986.

ANDREW, W.; HICKMAN, C. P. Histology of the vertebrates: a comparative text. Saint Louis, Mosby, 1974, 439p.

ANGELESCU, V.; GNERI, F. S. Adaptaciones del aparato digestivo al régimen alimentício in algunos peces del rio Uruguay e del rio de la Prata. Rev. Inst. Invest. Mus. Argent. Cienc. Nat., v. 1, p. 161-272, 1949.

ARMBRUSTER, J. W. Modifications of the digestive tract for holding air in loricariid and scoloplacid catfishes. Copeia, v. 3, p. 663-675, 1998.

BANCROFT, J.D.; GAMBLE, M. Theory and practice of histological techniques. New York: Churchill Livingstone, 2002. 796 p.

BANCROFT, J.D.; STEVENS, A. Theory and practice of histological methods. 2. ed. New York: Churchill Livingstone, 1982. 662 p.

BARRINGTON, E. J. W. The alimentary canal and digestion. In: BROW, M. E. The physiology of fishes. New York: Academic Press, 1957. v. 1, p. 109-161. 
BERTIN, L. Appareil digestif. In: GRASSÉ, P. P. Traite de zoologie. Paris: Masson, 1958. v. 13, t. 2, p. 1248-1302.

BISHOP, C. M.; ODENSE, P.H. Morphology of the digestive tract of the cód, Gadus morhua. Journal of the Fisheries Research Board of Canada., Ottawa, v. 23, p. 1607-1615, 1966.

BLAKE, I. H. Studies on the comparative histology of the digestive tube of certain teleost fishes. II: A bottom-feeding fish, the sea-robin. Prionotus carolinus. J. Morphol., v. 60, p. 77-102, 1936.

BLAKE, I. H. Studies on the comparative histology of the digestive tube of certain teleost fishes. I: A predacious fish, the sea bass Centropistes striatus. J. Morphol., v. 50 , p. 39-70, 1930.

BOCKMAN, D. E.; COOPER, M. D. Pinocytosis by epithelium associated with lymphoid follicles in the bursa of Fabricius, appendix and Peyer's patches. An electron microscopic study. Am. J. Anat., v. 136, p. 455-478, 1973.

BORGES, L. O. Contribuição ao estudo anátomo-histológico e ultra-estrutural do trato digestivo de Plecostomus commersonii (Cuvier e Valenciennes, 1840) Pisces. 1981. 95 f. Dissertação (Mestrado em Biologia Celular e Molecular) Universidade Federal do Paraná, Curitiba, 1981.

BRITSKI, H. A.; SATO, Y.; ROSA, A. B. S. Manual de identificação de peixes da região de Três Marias (com chaves de identificação para os peixes da Bacia do São Francisco). 3. ed. Brasília: CODEVASF, 1988. 115 p.

BRITSKI, H. A.; SILIMON de S.; KEVE de S. Peixes do Pantanal - Manual de identificação. Brasília: Embrapa, 1999. 184 p.

BUDDINGTON, R. K.; KROGDAHAL, A.; BAKKE-McKELLEP, A. M. The intestine of carnivorous fish: structure and functions and the relations with diet. Acta Physiol. Scand., v. 161, p. 67-80, 1997. Suplement 638.

BURNSTOCK, G. The morphology of the gut of the Brown trout (Salmo trutta). $\mathbf{Q}$. Journal of Microscopy Science, v. 100, p. 183-198, 1959.

CHAUDRY, H. S.; KHANDELWAL, O. P. The anatomy and histology of the alimentary tract of Oreinus plagiostomus. Annotationes Zoologicae Japonenses, v. 34, n. 134-152, 1961.

CLARKE, A. J.; WITCOMB, D. M. A study of the histology and morphology of the digestive tract of the common eel Anguilla anguilla. Journal of fish biology, v. 16, p. 159-170, 1980.

CURRY, E. The histology of the alimentary canal of the carp (Cyprinus carpio communis). J. Morphol., v. 65, p. 53-78, 1939. 
DEGUARA, S.; JAUNCEY, K.; AGIUS, C. Enzyme activities and pH variations in the digestive tract of gilthead sea bream. Journal of Fish Biology, v. 62, p. 1033-1043, 2003.

DÍAZ, A. O.; GARCIA, A. M.; DEVINCENTI, C. V.; GOLDEMBERG, A. L. Morphological and histochemical characterization of the mucosa of the digestive tract in Engraulis anchoita (Hubbs and Marini, 1935). Anatomia, Histologia, Embryologia, v. 32, p. 341-346, 2003.

DOMITROVIC, H. A.; MOREIRA, J. E. Microscopia eletrônica de varredura do trato digestivo do "sabalo" (Prochilodus platensis, Holmberg, 1880; Pisces, Prochilodontidae). Revista Brasileira de Ciência Morfologica, v. 1, p. 21-30, 1984.

EVANS, D. H. Physiology of Fishes. CRC Press: Florida. 1993.

EZEASOR, D. N. Light and electron microscopic studies on the oesophageal epithelium of the rainbow trout, Salmo gairdneri. Anat. Anz., v. 155, p. 71-83, 1984.

EZEASOR, D. N.; STOKOE, W. M. Scanning electron microscopic study of the gut mucosa of the rainbow trout, Salmo gairdneri. Journal of fish biology, v. 17, p. 529540, 1980.

FERRI, S. Contribuição ao estudo morfológico e histoquímico do esôfago, estômago e intestino de Xenodon meremii (Wagler, 1824) Ophidia. São Paulo, 1971. p. Tese (Livre-Docência) - Instituto de Ciências Biomédicas, Universidade de São Paulo, São Paulo, 1971.

FLORES QUINTANA, C. I.; PEREYRA, L. A.; DOMITROVIC, H. A.; ROUX, J. P.; SAMPIETRO, J. C. Estructura histologica del aparato digestivo del surubí (Pseudoplatystoma coruscans y Pseudoplatystoma fasciatum) (Pisces, Siluriformes). In: ACTA REUNIÓN DE COMUNICATIONES CIENTÍFICAS Y TECNOLÓGICAS UNNE, 2., 1997, [s. I.]. Proceedings... p. 17-20.

FLOWERDEW, M. W.; GROVE, D. J. Some observations of the effects of body weight, temperature, meal size and quality on gastric emptying time in the turbot, Scophthalmus maximus (L.) using radiography. Journal of Fish Biology, v. 14, p. 229-238, 1979.

FUGI, R.; AGOSTINHO, A. A.; HAHN, N. S. Trophic Morphology of five BenthicFeeding fish Species of a Tropical Floodplain. Revista Brasileira de Biologia, v. 61 (1), p. 27-33, 2001.

GALVÃO, M. S. N.; FENERICH-VERANI, N.; YAMANAKA, N.; OLIVEIRA, I. R. Histologia do sistema digestório da tainha Mugil platanus (Günther, 1880) (Osteichthyes, Mugilidae) durante as fases larval e juvenil. Boletim do Instituto da Pesca, v. 24, p. 91-100, 1997. 
GARCÍA HERNÁNDEZ, M. P. ; LOZANO, M. T.; ELBAL, M. T.; AGULLEIRO, B. Development of the digestive tract of sea bass (Dicentrarchus labrax L.), Light and electron microscopic studies. Anatomy and Embryology, v. 204, p. 39-57, 2001.

GEISTDOERFER, P. Morphologie et histologie de l'appareil digestif des Macrouridae (Teleosteens) II. Histologie de l'appareil digestif. Cybium, v. 5, p. 3-39, 1981.

GEORGOPOULOU, U.; SIRE, M. F.; VERNIER, J. M. Macromolecular absoption of proteins by epithelial cells of the posterior intestine segment and their intracellular digestion in the rainbow trout. Biol. Cell., v. 53, p. 269-282, 1985.

GEORGOPOULOU, U.; VERNIER, J. M. Local immunological response in the posterior intestinal segment of the rainbow trout after oral administration of macromolecules. Dev. Comp. Immunol., v. 10, p. 529-537, 1986.

GERRITS, P. O. Staining procedures for tissues embedded in 2-hydroxyethyl methacrilate. Mikroskopie (Wien), v. 5, p. 321-328, 1983.

GODINHO, H. Estudos anatômicos sobre o trato digestivo de um siluroidei Pimelodus maculatus, Lacépède. Revista Brasileira de Biologia, v. 27, p. 425-433, 1967.

GODINHO, H. ; TOKUMARU, M. ; FERRI, A. G. Histologia do trato digestivo de Pimelodus maculatus Lacépède, 1803 (Pisces, Siluroidei). Revista Brasileira de Biologia, v. 30, p. 583-593, 1970.

GOMES, R. M. Estudo morfológico e histoquímico (Carbohidratos) do trato digestivo de Rhamidia branneri (Hasemman, 1911) Pisces. Curitiba, 1981. p. Dissertação (Mestrado) - Universidade Federal do Paraná, Curitiba, 1981.

GROVE, D. J. L.; OIZIDES, L. G.; NOTT, J. Satiation amount, frequency of feeding and gastric emptying rate in Salmo gairdneri. Journal of Fish Biology, v. 12, p. 507516, 1979.

HALE, P. A. The morphology and histology of the digestive systems of two freshwater teleosts, Poecilia reticulate and Gasterosteus aculeatus. Journal of Zoology, v. 146, p. 132-149, 1965.

HERNANDEZ-BLAZQUEZ, F. J.; Estudo microscopico (óptico e eletrônico) e histoquímico do esôfago e estômago cárdico de Prochilodus scrofa, Steindachner, 1881. 1986. 192 p. Dissertação (Mestrado) - Instituto de Ciências Biomédicas, Universidade de São Paulo. São Paulo, 1986.

HERNANDEZ-BLAZQUEZ, F. J.; FERREIRA, N.; CARVALHO, C. A. F.; FERRI, S. Morphological aspects of the esophagus and stomach of a freshwater iliophagous fish under scanning electron microscopy. Gegenbaurs Morphologisches Jahrbuch Leipzig, v. 136, p. 119-125, 1990. 
HERNANDEZ-BLAZQUEZ, F. J.; NACHI, A. M.; FERRI, S.; FERREIRA, N. Fat Intestinal Absorption in the Catfish- A Histochemical Study in Glycol Methacrylate Embedded Tissue. Gegenbaurs morphol. Jahrb. Leipzig, v. 135, n. 6, p. 941-946, 1989.

HIDALGO, F.; ALLIOT, E. La digestion en los peces. In: ESPINOSA DE LOS MONTEROS, J.; LABARTA, U. Nutrición en acuicultura I. Madrid: Plan de Formación de Técnicos Superiores en Acuicultura, 1987. p. 85-107.

HILSDORF, A. W. S.; MOREIRA, R. G. Aqüicultura. Scientific American. São Paulo, ano 2, n. 22, p. 24-29, 2004.

HOLSTEIN, B. Gastric acid secretion in a teleostean fish: a method for the colletion of gastric efluence from a swimming fish and its response to histamine and pentagastrin. Acta Physiology Scandinavian, v. 95, p. 717-723, 1975.

IRVING, P. W. Sexual dimorphism in club cell distribution in the European minnow and immunocompetence signaling. Journal of Fish Biology, v. 48, p. 80-88, 1996.

IWAI, T. Fine structure of gut epithelial cells of larval and juvenile carp during absorption of fat and protein. Arch. Histol. JPN., v. 30, p. 183-189, 1969.

JOBLING, M. Mythical models of gastric emptying and implications for food consumption studies. Environmental Biology of Fishes, v. 16, p. 35-50, 1986.

JUNGER, H.; KOTRSCHOR, K.; GOLDCHMID, A. Comparative morphology and ecomorphology of the gut in European cyprinids. Journal of Fish Biology, v. 34, p. 315-326, 1989.

JUNQUEIRA, L. C.; CARNEIRO, J. Histologia Básica. 9. ed. Guanabara Koogan: Rio de Janeiro. 1999.

KAISERLIAN, D. The intestinal epithelial cell: A non-conventional type of antigenpresenting cell. J. Ultrast. Res., v. 4, p. 32-39, 1995.

KAPOOR, B. G.; SMIT, H.; VERIGHINA, I. A. The alimentary canal and digestion in teleosts. Advances in Marine Biology, v. 13, p. 109-239, 1975.

KESSLER, R. O.; DIAS, M. I.; OLIVEIRA, E. F. Estudo histológico do estômago de Prochilodus sp. (Osteichthyes: Curimatidae). Acta Biológica Leopoldina, Universidade Vale do Rio dos Sinos, v. 1, p. 55-84, 1979.

KUCHINSKI, F. B. Anatomia, Histologia e Histoquímica do Estômago de Colossoma mitrei, Berc, 1895 (Pacu-Caranha) nos Estágios Alevino Jovem, Peixe Jovem e Adulto. 1985. p. Tese (Doutorado) - Universidade Mackenzie, São Paulo, 1985. 
KUPERMAN, B. I.; KUZ'MINA, V. V. The ultrastructure of the intestinal epithelium in fishes with different types of feeding. Journal of fish biology, v. 44, p. 181-193, 1994.

LAGLER, K. F.; BARDACH, J. E.; MILLER, R. R.; PASSINO, D. R. Ichthyology. New Jersey: John Wiley \& Sons, 1977, 506 p.

LANGILLE, R. M.; YOUSON, J. H. Morphology of the intestine of prefeeding and feeding adult lampreys (Petromyzon marinus L.) The mucosa of the diverticulum, anterior intestine and transition zone. J. Morphol., v. 182, p. 39-61, 1984.

LAUDER, G. V.; LIEM, K. F. The evolution and interrelationships of the Actinopterygian fishes. Bulletin of the Museum of Comparative Zoology, v. 150, n. 3, p. 95-197, 1983.

LIEM, K. Functional morphology of the integumentary, respiratory and digestive systems of the synbranchoid fish Monopterus albus. Copeia, v. 2, p. 375-388, 1967.

LUNDSTEDT, L. M.; MELO, J. F. B.; MORAES, G. Digestive enzymes and metabolical profile of Pseudoplatystoma coruscans (Teleostei: Siluriformes) in response to diet composition. Comp. Biochem. Physiol., v. 137 B, p. 331-339, 2004.

MAGID, A. M. A. The epithelium of the gastro-intestinal tract of Polypterus senegalus (Pisces: Brachipterygii). Journal Morphological, v. 146, p. 447-456, 1975.

MANGETTI, A. J. Desenvolvimento histomorfológico do trato digestório de larvas de pintado Pseudoplatystoma coruscans (Agassiz, 1829). 2006. $94 \mathrm{f}$. Dissertação (Mestrado) - Faculdade de Medicina Veterinária e Zootecnia, Universidade de São Paulo, São Paulo, 2006.

MANNING, M. J. Fishes In: R. J. TURNER ed. Immunology: A Comparative Approach. Chichester: JOHN WILEY \& SONS, 1994, p. 69-100.

MARTIM, T. J.; BLABER, S. J. M. Morphology and histology of the alimentary tract of Ambassidae (Cuvier) (Teleostei) in relation to feeding. Journal Morphological, v. 182, p. 295-305, 1984.

MIRANDA, M. O. T.; RIBEIRO, L. P. Características zootécnicas do surubim (Pseudoplatystoma coruscans) In: MIRANDA, M. O. T. (Org.) Surubim. Belo Horizonte: IBAMA, 1997. v. 19, p. 43-56. (Coleção Meio Ambiente, Série Estudos Pesca).

MOHSIN, S. M. Comparative morphology and histology of the alimentary canals in certain groups of indian teleosts. Acta Zool., v. 43, p. 79-133, 1962. 
MORAES, M. F. P. G.; BARBOLA, I. F. Hábito alimentar e morfologia do tubo digestivo de Hoplias malabaricus (Osteichthyes, Erythrinidae) da Lagoa Dourada, Ponta Grossa, Paraná, Brasil. Acta Biol. Par., v. 24, p. 1-23, 1995.

MORRISON, C. M.; WRIGHT JR, J. R. A study of the histology of the digestive tract of the Nile tilapia. Journal of Fish Biology, v. 54, p. 597-606, 1999.

NACHI, A. M. Absorção de macromoléculas e atividade fagocitária no epitélio intestinal de Prochilodus scrofa. 1993. 81p. Tese (Doutorado) - Instituto de Ciências Biomédicas, Universidade de São Paulo, São Paulo, 1993.

NACHI, A. M. Intestino de Prochilodus scrofa (Curimbatá): Estudo histológico, histoquímico de glicoconjugados e da absorção de lipídeos utilizando diferentes métodos de inclusão. 1988. 126p. Dissertação (Mestrado) - Instituto de Ciências Biomédicas, Universidade de São Paulo, São Paulo, 1988.

NOAILLAC-DEPEYRE, J. ; GAS, N. Mise en évidence d'une zone adaptée au transport des ions dans l'intestin de la Carpe commune (Cyprinus carpio L.). C. R. Acad. Sci., Paris, v. 276, p. 773-776, 1973.

NOAILLAC-DEPEYRE, J.; GAS, N. Étude cytophysiologique de l'épithelium intestinal du poisson-chat (Ameiurus nebulosus L.). Can. J. Zool., v. 61, p. 25562573, 1983.

NOAILLAC-DEPEYRE, J.; GAS, N. Electron microscopic study on the gut epithelium of the tench (Tinca tinca L.) with respect to its absorptive functions. Tissue \& Cell, v. 8, p. 511-530, 1976.

NOAILLAC-DEPEYRE, J.; GAS, N. Fat absorption by the enterocytes of the carp (Cyprinus carpio L.). Cell and Tissue Research, v. 155, p. 353-365, 1974.

NOAILLAC-DEPEYRE, J.; GAS, N. Structure and function of intestinal epithelial cells in the perch (Perca fluviatus L.). Anatomical Record, v. 195, p. 621-640, 1979.

ODUM, H. E. The ecological significance of fine particle selection by striped mullet Mugil cephalus. Limnol. Oceanogr., v. 13, p. 92-97, 1968.

PARK, J. Y.; KIM, I. S. Histology and mucin histochemistry of the gastrointesinal tract of the mud loach, in relation to respiration. Journal of Fish Biology, v. 58, p. 861872, 2001.

PETRERE JR., M. A pesca de água doce no Brasil. Ciência Hoje, v. 19, n. 110, p. 28-33. 1995.

PETRINI, L. M. Sobre a presença de capilares intraepteliais na mucosa do estômago do cascudo (Plecostomus plecostomus). Ciência e Cultura, São Paulo, v. 13, p. $175,1961$. 
PODKOWA, D.; GONIAKOWSKA-WITALINSKA, L. Morphology of the air-breathing stomach of the catfish Hypotomus plecostomus. Journal of Morphology, v. 257, p.147-163, 2003.

PY-DANIEL, L. H. R. Sistemática dos Loricariidae (Ostariophysi, Siluroidei) do complexo de lagos do Janauacá, Amazonas, e aspectos de sua biologia e ecologia. 1984. 278 p. Dissertação (Mestrado) Instituto Nacional da Amazônia, Fundação Universidade do Amazonas, 1984.

RAY, K. A.; MOITRA, S. K. On the morpho-histology of the alimentary tract in the Climbin perch (anabas testudineus) in relation to food and feeling habits. Gegenbaurs Morphologisches Jahrbuch Leipzig, v. 5, p. 778-798, 1982.

REIFEL, C. W.; TRAVILL, A. A. Structure and carbohydrate histochemistry of the esophagus in ten teleostean species. European Journal of Morphology, v. 152, n. 3, p. 303-314, 1977.

REIFEL, C. W.; TRAVILL, A. A. Structure and carbohydrate histochemistry of the stomach in eight species of teleosts. J. Morphol., v. 158, p. 155-166, 1978.

ROMBOUT, J. H. W. M.; LAMERS, C. H. J.; HELFRICH. M. H.; DEKKER, A.; TAVERNE-THIELE, J. J. Uptake and transport of intact macromolecules in the intestinal epithelium of carp (Cyprinus carpio L.) and the possible immunological implications. Cell Tissue Res., v. 239, p. 519-530, 1985.

ROMBOUT, J. H. W. M.; van den BERG, A. A. Immunological importance of the second segment of the carp (Cyprinus carpio L.) I. Uptake and processing of antigens by epithelial cells and macrophages. J. Fish Biol., v. 35, p. 13-22, 1989.

SANTOS, E. Peixes da Água Doce (Vida e costumes dos peixes do Brasil). Belo Horizonte: Ed. Itatiaia, 1981. 267 p. (Coleção Zoológica Brasílica, v. 2).

SANTOS, E. Peixes da água doce. 4. ed. Belo Horizonte: Editora Itatiaia Limitada, 1987. v. 2, 267 p.

SANTOS, M. T. M.; MENDES, A. F.; NEPOMUCENO, H. Estudos histoquímicos do tubo digestivo de Plagioscian equamossimus (Heckel, 1840). Rev. Med. Univ. Fed. Ceará, v. 19 (1/2), p. 19-25, 1979.

SATO, Y.; CARDOSO, E. L.; SALLUM, W. B. Reprodução induzida do Surubim (Pseudoplatystoma coruscans) da bacia do São Francisco. In: ENCONTRO ANUAL DE AQUICULTURA, 6., 1988, Belo Horizonte. Anais... Belo Horizonte: Associação Mineira de Aqüicultura- AMA, 1988. p. 20.

SATORA, L. Histological and ultrastructural study of the stomach of the air-breathing Ancistrus multispinnis (Siluriformes, Teleostei). Canadian Journal of Zoology, v. 76, p. 83-86, 1998. 
SCHMITZ, E. H.; BAKER, C. D. Digestive anatomy of the gizzard shad, Dorosoma cepedianum and the threadfin shad, $D$. petenense. Transactions of the American Microscopical Society, v. 88, p. 525-546, 1969.

SCOCCO, P.; CECCARELLI, P.; MENGHI, G. Glycohistochemistry of the Tilapia spp. Stomach. J. Fish Biol., v. 49, p. 584-593, 1996.

SEIXAS FILHO, J. T.; FONSECA, C. C.; OLIVEIRA, M. G. A.; DONZELE, J. L.; MENIN, E. Determinação do sistema endócrino difuso nos intestinos de três teleostei (Pisces) de água doce com hábitos alimentares diferentes. Rev. Bras. Zootec., v. 30, n. 5, p. 1403-1408, 2001a.

SEIXAS FILHO, J. T.; MOURA BRÁS, J.; GOMIDE, A. T. M., OLIVEIRA, M. G. A.; DONZELE, J. L.; MENIN, E. Anatomia funcional e morfometria do intestino no Teleostei (Pisces) de água doce surubim (Pseudoplatystoma coruscans- Agassiz, 1829). Rev. Bras. Zootec., v. 30, n. 6, p. 1670-1680, 2001 b.

SILVA, J. M.; HERNANDEZ-BLAZQUEZ, F. J.; JULIO JR., H. F. A new accessory respiratory organ in fishes: morphology of the respiratory purses of Loricariichthys platymetopon (Pisces, Loricariidae). Annales des Sciences Naturelles Zoologie Paris, v. 18 (3), p. 93-103, 1997.

SINHA, G. M. Functional light and scanning electron microscopical studies on the palate in a freshwater major carp, Cirrhinus mrigala (Hamilton), during the young and adult stages. Zoologische Jahrbücher Für Anatomie, v. 102, p. 361-380, 1979.

SINHA, G. M.; MOITRA, S. K. Studies on the functional morpho-histology of the alimentary canal of an indian freshwater major carp, Labeo rohita (Hamilton) during its different life-history stages. Anatomischer Anzeiger, v. 138, p. 222-238, 1975.

SIRE, M. F.; LUTTON, C.; VERNIER, J. M. New views on intestinal absorption of lipids in teleostean fishes : an ultrastructural and biochemical study in the rainbow trout. J. Lipid Res., v. 27, p. 81-94, 1981.

SIS, R. F.; IVES, P. J.; JONES, D. M.; LEWIS, D. H.; HAENSLY, W. E. The microscopic anatomy of the esophagus, stomach and intestine of the channel catfish, Ictalurus punctatus. J. Fish Biol., v. 14, p. 179-186, 1979.

SMIT, $\mathrm{H}$. Influence of temperature on the rate of gastric juice secretion in the brown bullhead, Ictalurus nebulosus. Comp. Biochem. Physiol., v. 21, p. 125-132, 1967.

SMITH, L. S. Digestive functions in teleost fish. In: HALVERT, J. E. (Ed.). Fish nutrition. Academic Press: San Diego, 1989. p. 331-421.

SOUZA, S. N. Avaliação da estrutura do aparelho digestório de alevinos de surubim, Pseudoplatystoma coruscans, Agassiz, 1829 (SILURIFORMES, SILUROIDEI, PIMELODIDAE) relacionado com sua capacidade de seleccionar e 
digerir o alimento. 1999. 95 f. Dissertação (Mestrado) - Universidade de Viçosa, Viçosa, 1999.

STROBAND, H. W. J.; DABROWSKI, K. R. Morphological and physiological aspects of the digestive system and feeding in freshwater fish larvae. La nutrition des poisons: actes du coloque. Paris: M. Fontaine, 1979.

STROBAND, H. W. J.; VAN DER VEEN, F. H. Localization of protein absorption during transport of food in the intestine of grasscarp Ctenopharyngodon idella (Val.). The Journal of Experimental Zoology, v. 218, p. 249-256, 1981.

SUICMEZ, M.; ULUS. E. A study of the anatomy, histology and ultrastructure of the digestive tract of Orthrias angorae (Steindachner, 1897). Folia Biológica, (Krakow). v. 53, n. 1-2, p. 95-100, 2005.

SUYEHIRO, Y. A study of the digestive system and feeding habits of fish. Japonese Journal Zoology, v. 10, p. 1-303, 1942.

TAN, C. K.; TEH, Y. F. The structure of the gut of a coral fish Chelmon rostratus Cuv. Okajimas Folia Anat. Jpn., v. 51, p. 63-80, 1974.

THOMAZ, S. M.; ROBERTO, M. C.; BINI, L. M. Caracterização limnológica dos ambientes aquáticos e influencia dos níveis fluviométricos. In: VAZZOLER, E. A. M.; AGOSTINHO, A. A.; HAHN, N. S. A planície de inundação do alto Rio Paraná: aspectos físicos, biológicos e socioeconômicos. Maringá: EDUEM, Nupélia, 1997. p. 73-102.

VEGA-VELEZ, M. La structure histologique typique du tube digestif dês poissons téléosteens. Tethys, v. 41, p. 163-174, 1972.

VEREGINA, I. A. Basic adaptation of the digestive system in bony fishes as a function of diet. J. Ichthyology, v. 30, n. 6, p. 897-907, 1990.

VERIGINA, I. A. Microscopic structure of the digestive tract of fishes of the genus Alepocephalus. Probl. Ichthyol., v. 18, p. 937-946, 1979.

VERIGINA, I. A. Digestive tract characteristics with respect to the absence of a stomach in the black sea blenny Blennius sanguinolentus. Probl. Ichthyol., v. 17, p. 964-968, 1978.

VERIGINA, I. A. The structure of the alimentary canal in some of the northern Blennioidei. I. The alimentary canal of the atlantic wolfish (Anarrhicas lupus). J. Ichthyol., v. 14, p. 954-958, 1974.

VERMA, S. R.; TYAGI, M. P. A comparative histological study of a few teleost fishes. Gegenbaurs morphological Jahrb., v. 120, p. 244-253, 1974. 
WEINREB, E. L.; BILSTAD, N. M. Histology of the digestive tract and adjacent structures of the rainbow trout Salmo gairdneri irideus. Copeia, v. 3, p. 194-204, 1955.

WEISEL, G. F. Anatomy and histology of the digestive system of the Paddlefis (Polyodon spathyla). Journal Morphological, v. 140, p. 243-256, 1973.

WELCOMME, R. L. River fisheries. In: FOOD AND AGRICULTURE ORGANIZATION OF THE UNITED NATIONS. FAO Fisheries Techinical Papers. Roma: FAO, 1985, p. 330. (FAO 262).

WESTERN, J. R. H.; JENNINGS, J. B. Histochemical demonstration of hydrochloric acid in the gastric tubules of teleosts using an in vivo Prussian blue technique.

Comp. Biochem. Physiol., v. 35, p. 879-884, 1970.

WOOTTON, R. J. Ecology of teleost fishes. Chapman \& Hall: London. 1990. 404 p. 


\section{APÊNDICE A}
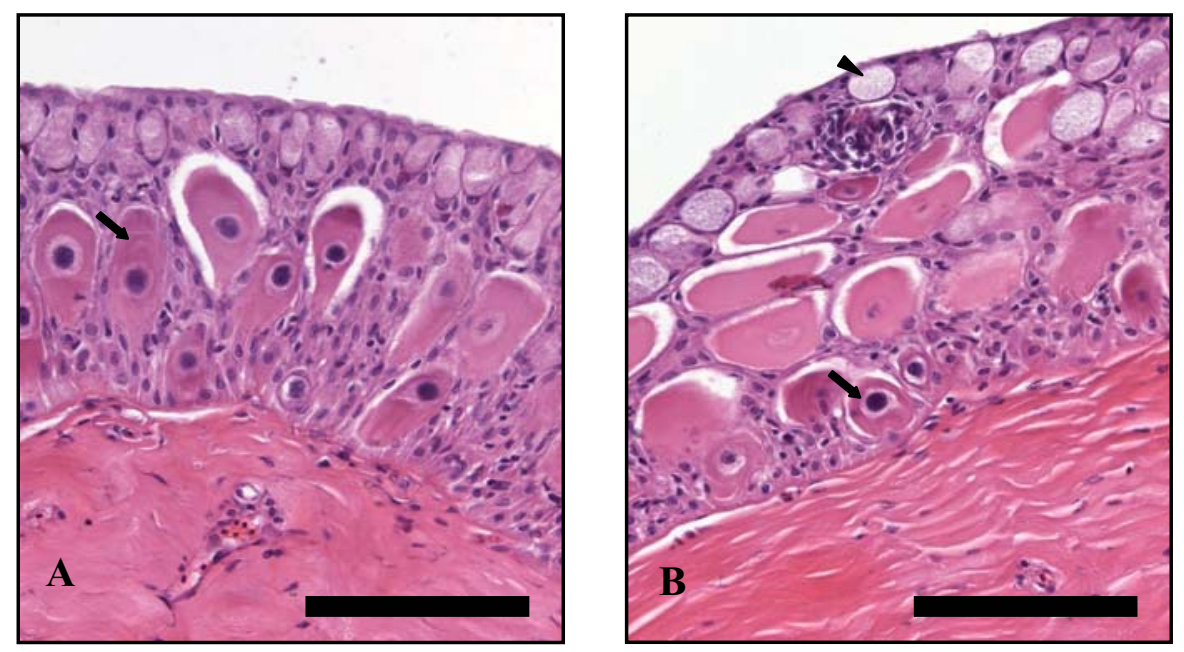

Figura 4 - Fotomicrografias do esôfago do pintado, A e B,mostrando epitélio do tipo pavimentoso estratificado não-queratinizado, com grande presença de células claviformes (seta), em diferentes fases de diferenciação celular e células mucosas presentes na superfície do epitélio (cabeça de seta). HE. Barra $=50 \mu \mathrm{m}$
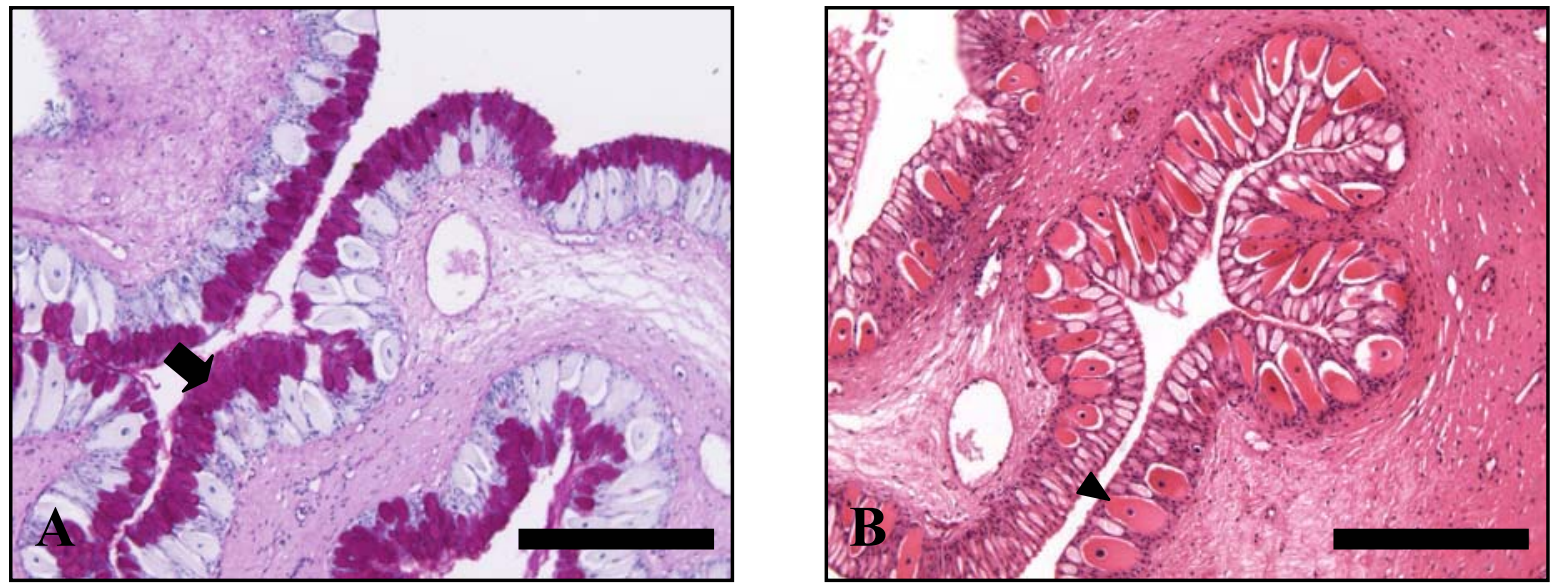

Figura 5 - Fotomicrografias do esôfago do pintado. A - Observa-se grande quantidade de células mucosas contendo mucopolissacarídeos neutros (seta). PAS. Barra $=200 \mu \mathrm{m}$. B llustrando a presença das células claviformes (cabeça de seta). HE. Barra $=200 \mu \mathrm{m}$ 


\section{APÊNDICE B}

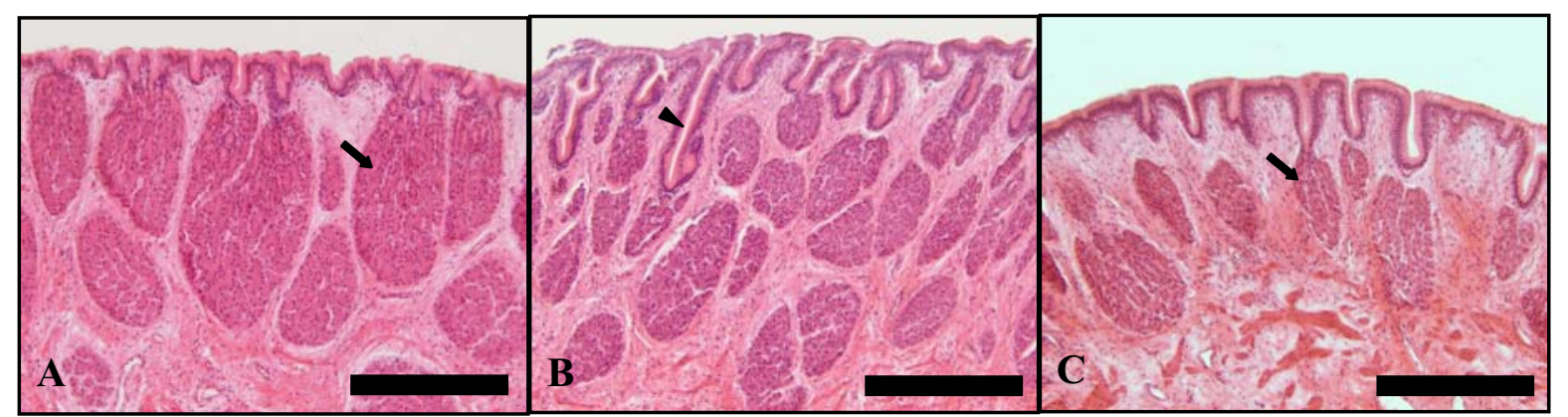

Figura 6 - Fotomicrografias do estômago de pintado ilustrando as suas diferentes regiões e a distribuição de glândulas gástricas (seta) no epitélio. A - Segmento proximal do estômago, com a presença de maiores e mais numerosas glândulas gástricas. HE. Barra $=200 \mu \mathrm{m}$. B - Segmento médio do estômago com menor quantidade de glândulas gástricas e mostrando a cripta gástrica (cabeça de seta). HE. Barra $=200 \mu \mathrm{m}$. C Segmento distal do estômago mostrando menor quantidade e tamanho de glândulas gástricas. HE. Barra $=200 \mu \mathrm{m}$
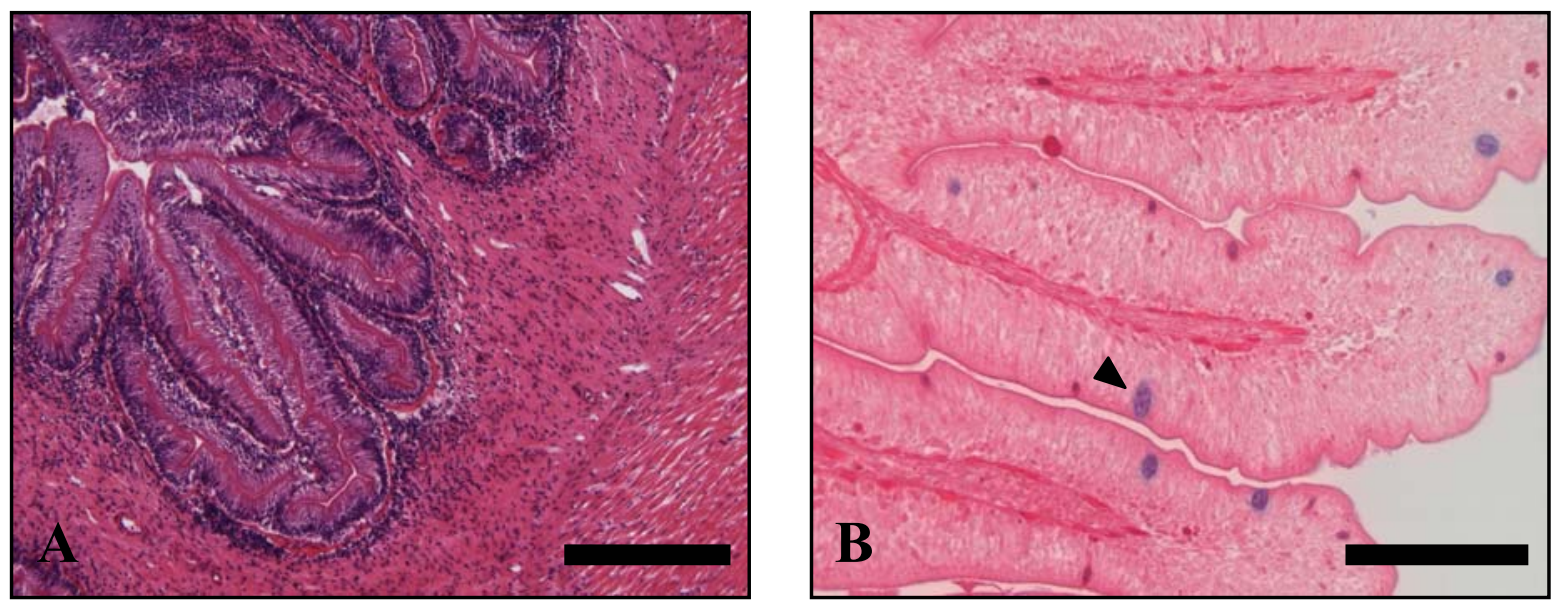

Figura 7 - Fotomicrografias do intestino proximal do pintado. A - Terceiro segmento onde se visualizam os vilos intestinais e estratigrafia desta região intestinal. HE. Barra $=200 \mu \mathrm{m}$. B - Epitélio do terceiro segmento do intestino proximal, evidenciando-se pouca freqüência de células mucosas coradas (cabeça de seta). PAS $+A B$. Barra $=100 \mu \mathrm{m}$ 


\section{APÊNDICE C}
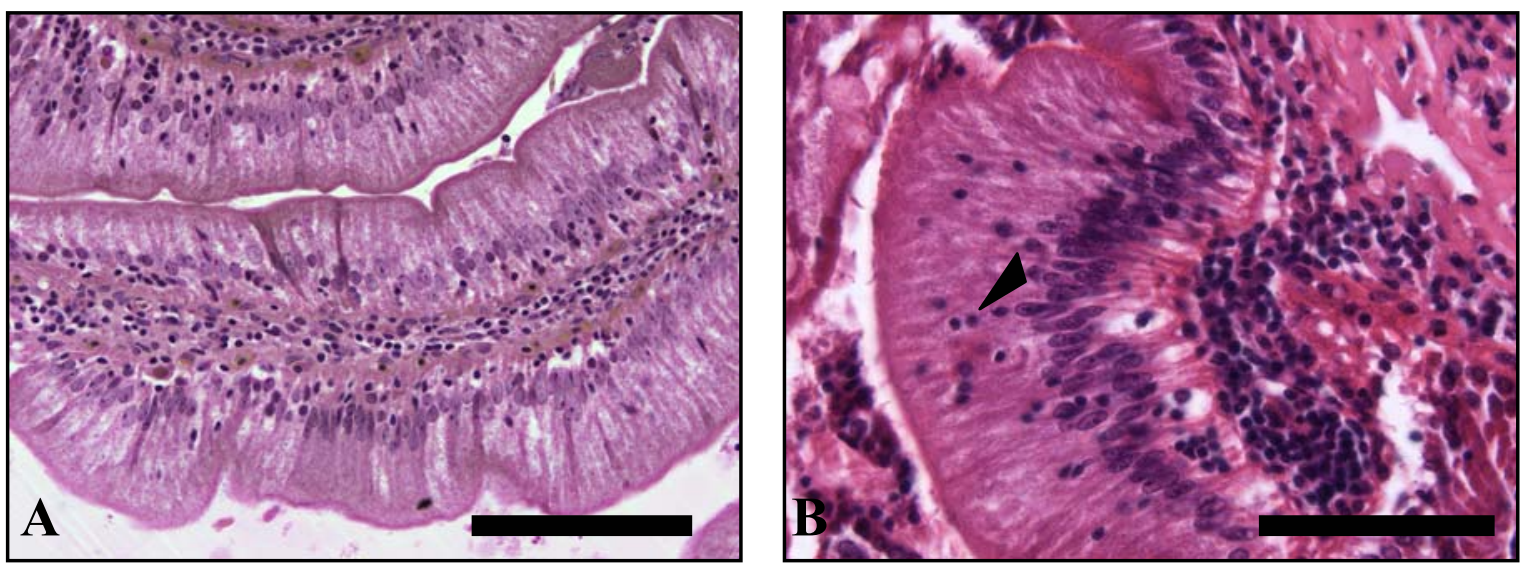

Figura 8 - Fotomicrografias do intestino proximal do pintado. A - Terceiro segmento onde se observa o epitélio do tipo colunar simples. HF. Barra $=50 \mu \mathrm{m}$. B - Epitélio do primeiro segmento do intestino proximal, onde podem ser observados vários linfócitos intraepiteliais (cabeça de seta). HF. Barra $=30 \mu \mathrm{m}$
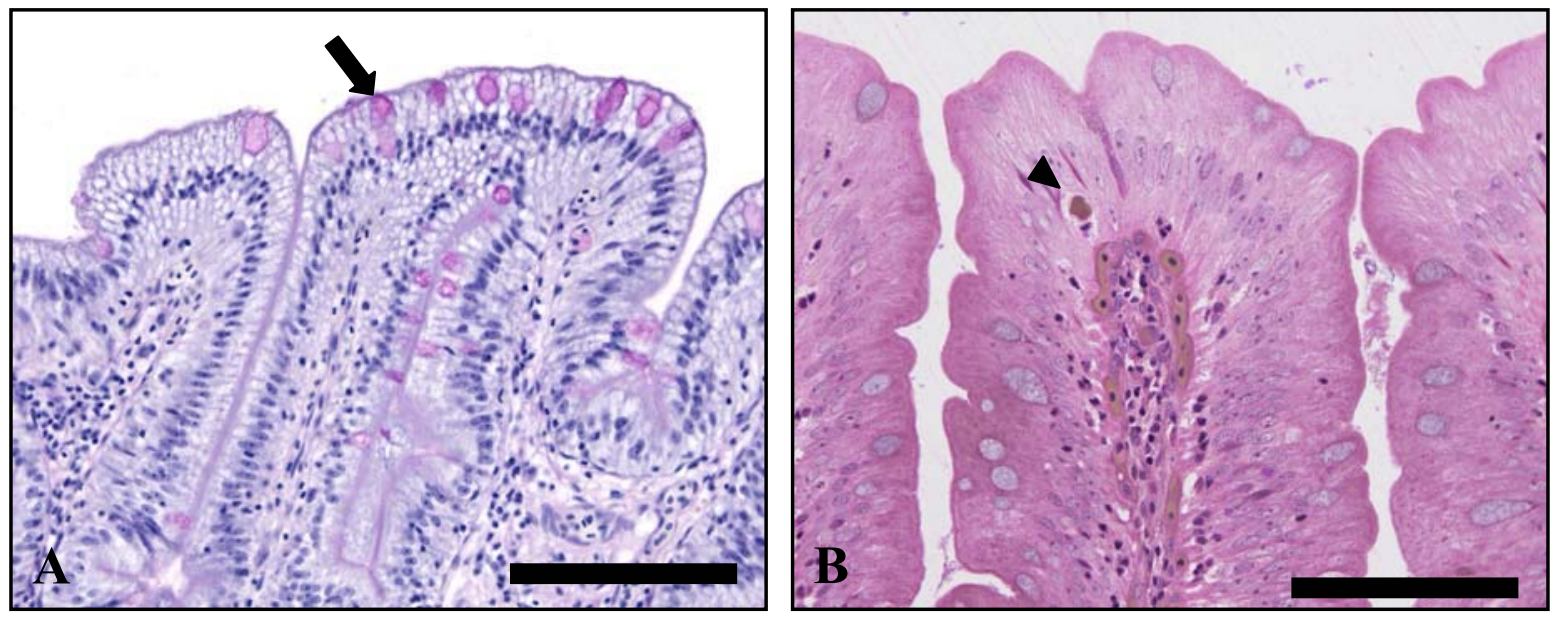

Figura 9 - Fotomicrografias do intestino médio do pintado. A - Primeiro segmento onde se observa o epitélio do tipo colunar simples, pouca freqüência de células caliciformes (seta). PAS. Barra $=50 \mu \mathrm{m}$. B - Epitélio do segundo segmento do intestino médio, onde nota-se detalhe de um macrófago intraepitelial (cabeça de seta). HF. Barra $=50 \mu \mathrm{m}$ 


\section{APÊNDICE D}

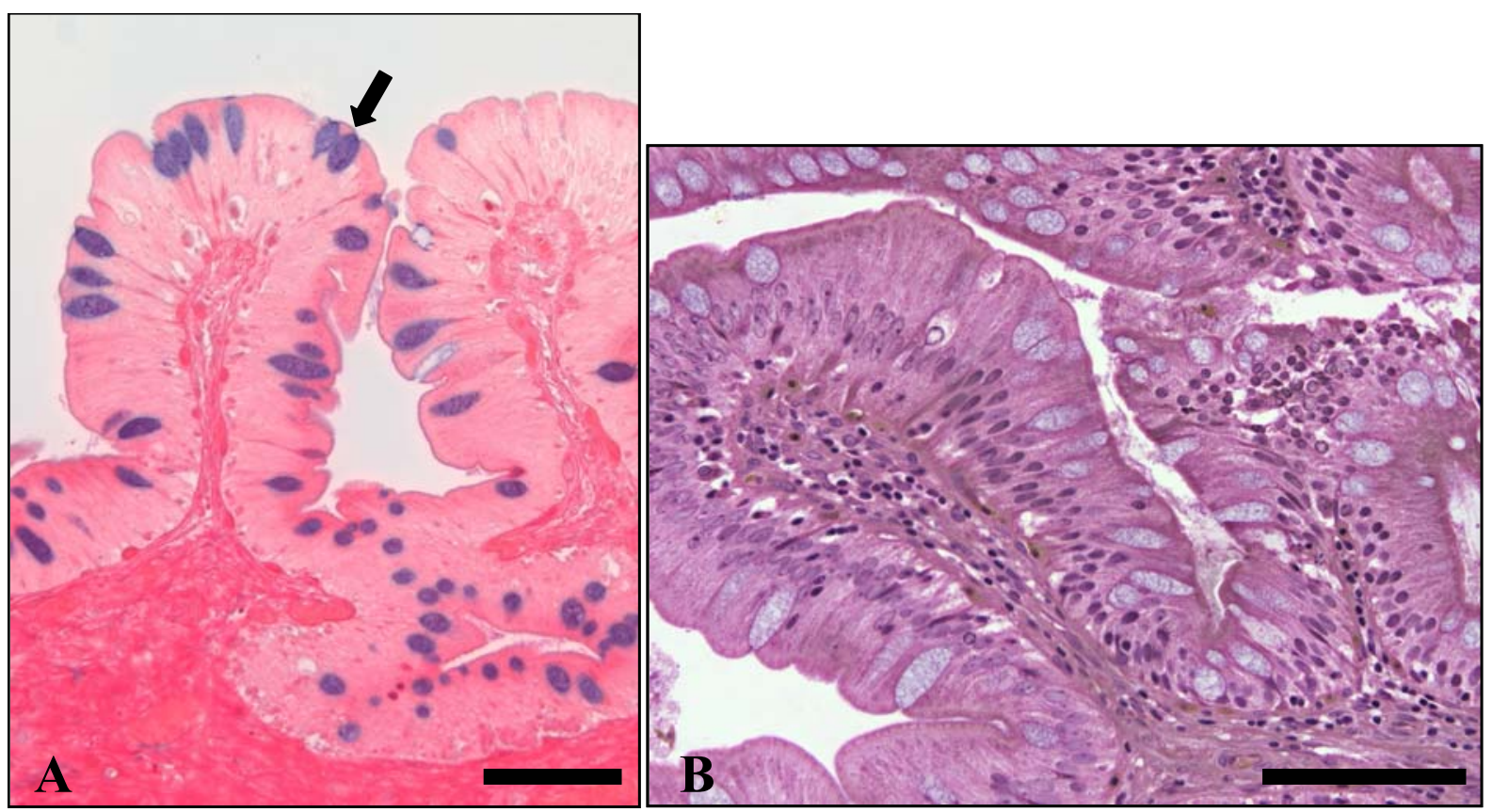

Figura 10 - Fotomicrografias do intestino médio do pintado. A - Terceiro segmento do intestino médio, destacando-se maior freqüência de células caliciformes coradas (seta), se comparado ao segmento anterior. PAS $+\mathrm{AB}$. Barra $=100 \mu \mathrm{m}$. B - Epitélio do terceiro segmento do intestino médio. HF. Barra $=50 \mu \mathrm{m}$
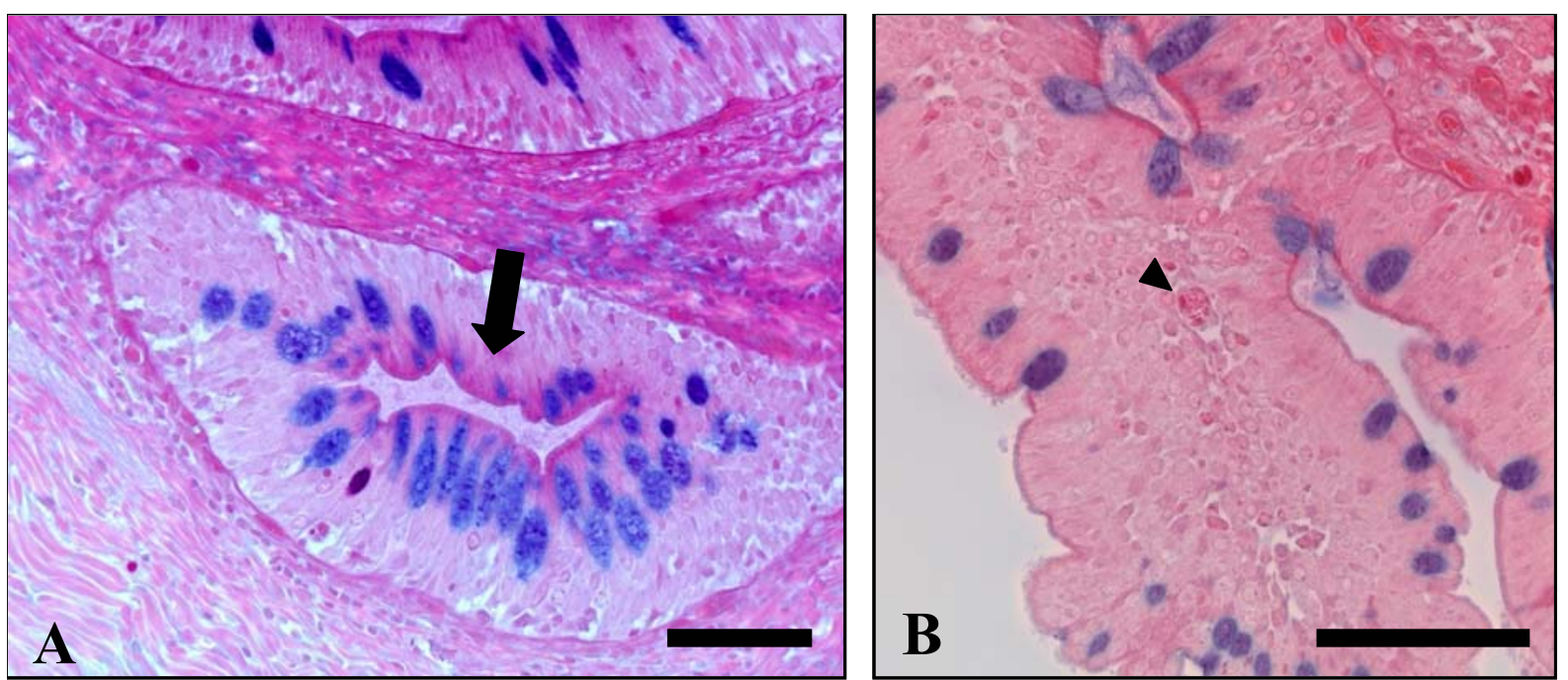

Figura 11 - Fotomicrografias do intestino médio de pintado. A - Glândula intestinal (seta) visualizada no sétimo segmento do intestino médio, apresentando células caliciformes coradas pelos métodos histoquímicos. PAS $+\mathrm{AB}$. Barra $=100 \mu \mathrm{m}$. B - Detalhe de um macrófago intraepitelial (cabeça de seta), visualizado no último segmento do intestino médio. PAS $+\mathrm{AB}$. Barra $=50 \mu \mathrm{m}$ 


\section{APÊNDICE E}
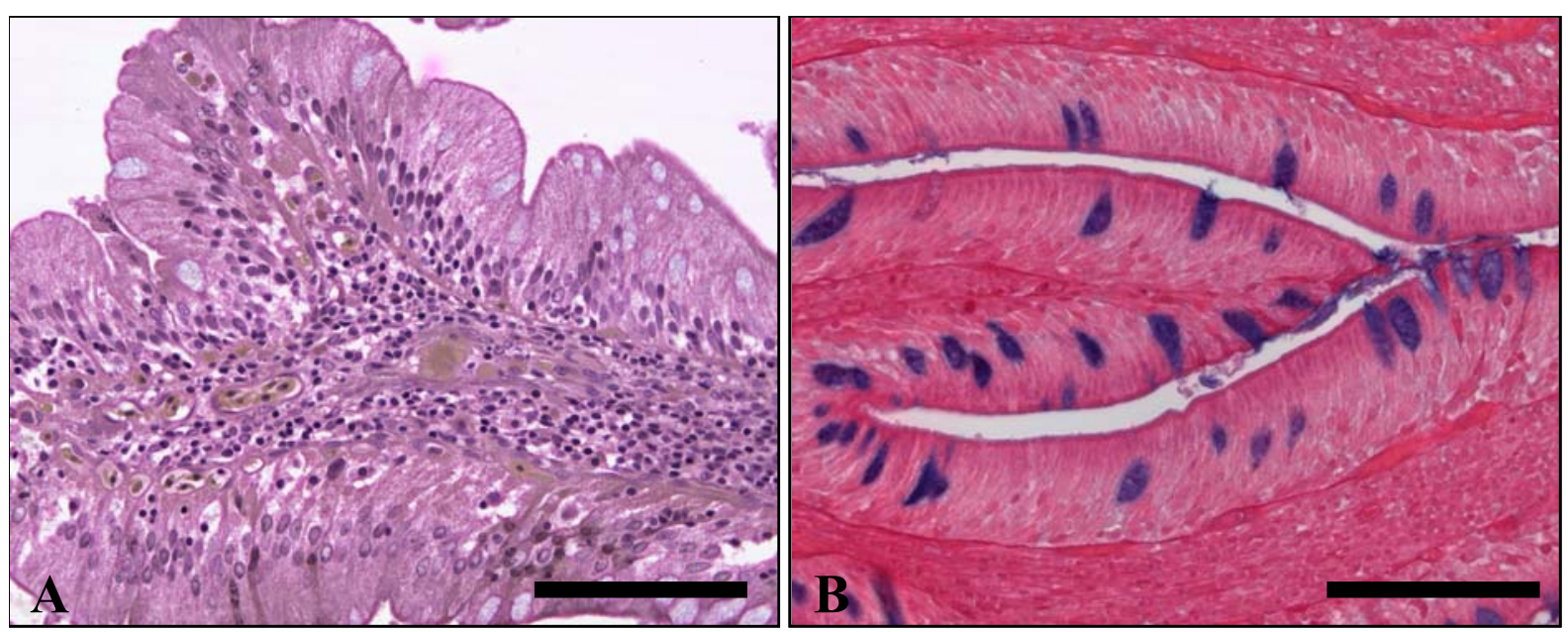

Figura 12 - Fotomicrografias do intestino distal ou reto de pintado. A - Epitélio do tipo colunar simples encontrado e borda em escova. HF. Barra $=50 \mu \mathrm{m}$. B - Freqüência de células caliciformes no primeiro segmento do intestino distal. PAS $+\mathrm{AB}$. Barra $=50 \mu \mathrm{m}$

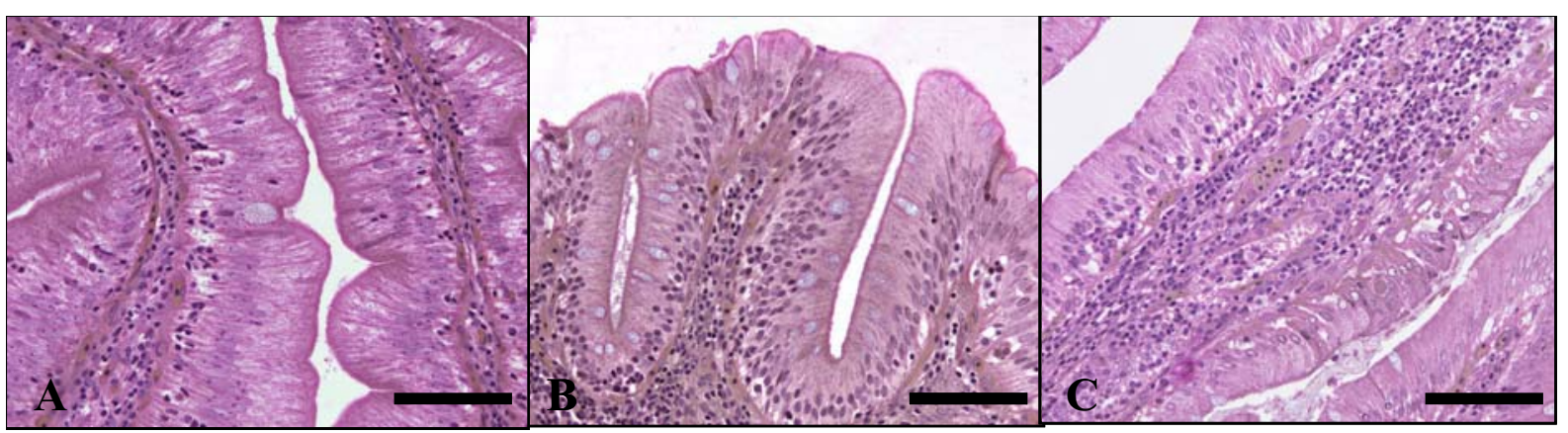

Figura 13 - Fotomicrografias ilustrando a diferença de altura do epitélio nas diferentes regiões intestinais. A - Epitélio do tipo colunar simples, no quarto segmento do intestino proximal. HF. Barra $=50 \mu \mathrm{m}$. B - Sétimo segmento do intestino médio. HF. Barra $=50$ $\mu \mathrm{m} \mathrm{C} \mathrm{-} \mathrm{Segundo} \mathrm{segmento} \mathrm{do} \mathrm{intestino} \mathrm{distal} \mathrm{ou} \mathrm{reto.} \mathrm{HF.} \mathrm{Barra}=50 \mu \mathrm{m}$ 